\title{
Articulating the Gaps in Financial Consumer Protection and Policy Choices for the Financial Conduct Authority- Moving Beyond the Question of Imposing a Duty of Care
}

\author{
Iris H-Y Chiu* and Alan H Brener**
}

\section{Key Points}

- We respond to the FCA's proposal to consider a statutory duty of care for financial services providers and argue that this is not the right solution to address perceived gaps in consumer or customer protection in financial services contexts.

- We analyse in detail the common law 'baggage' in the interpretation of the 'duty of care' and explore why it does not meet the purposes set out in the FCA's consultation paper. We also explore in comparison the general 'duty of best interests' under Australian law and the US federal fiduciary duty imposed on financial advisers.

- We offer a four-fold clarification of the gaps in financial consumer and customer protection under the existing regulatory regime and argue that these better capture the real concerns regarding shortfalls in law and regulation.

- We suggest that the FCA needs to consider if the 'scope' of protection offered to the three types of customers financial services firms need to classify are well designed. In particular, retail customers may not be adequately protected in non-advisory contexts, and borderline professional customers are given too little protection due to aggressive market practices in financial transactions.

- We suggest that the FCA needs to consider if standards of protection can be improved in order to incentivize good behavior on an ex ante basis and to avoid excessive proceduralisation. We suggest generally-framed duties can be added to the Treating Customers Fairly principle and the specific regulatory duties found in the MiFID and COBS.

- We suggest that the FCA needs to consider its deficiencies in its enforcement policy and practice which have given rise to concerns in independent reports and enforcement cases.

- Finally, we suggest that the FCA needs to consider the spectrum of redress options available to financial customers and consumers and address the weaknesses in the spectrum of options. Ideally we urge the FCA to take leadership in coupling public enforcement with customer restitution but as we do not see practical indications by the FCA towards this, it is crucially important to boost access to private litigation by aggrieved financial customers.

\section{Introduction}

At risk of offering a lame bullet to address stakeholders' complaints ${ }^{1}$ that financial outcomes for consumers can be improved, the UK Financial Conduct Authority has embarked on a broadly-framed consultation on whether the introduction of a duty of care for financial services providers addresses

\footnotetext{
*Professor of Corporate Law and Financial Regulation, University College London

** PhD (QMUL), Teaching Fellow, University College London, former adviser to the Banking Standards Board and Head of Regulatory Policy, Santander UK.

${ }^{1}$ The duty of care is proposed by the Financial Consumer Panel, which is one of the four stakeholder panels that the FCA has a duty to consult, s1Q, Financial Services and Markets Act 2000 as amended by the Financial Services Act 2012.
} 
gaps in the current regulatory regime, has the potential to improve financial services providers' conduct and consumer outcomes, and prevent consumer harms. ${ }^{2}$

The perception of poor consumer treatment as well as outcomes is widespread. The mis-selling of personal protection insurance over the last two decades has become the poster-episode illustrating the failure of consumer confidence in financial services. ${ }^{3}$ Adverse perceptions of the financial services industry continued with revelations of how small businesses were being 'ripped off' by the interest rate hedging products sold by their lenders, ${ }^{4}$ and how the largely nationalised Royal Bank of Scotland ran a small business restructuring unit that conducted its relations with customers in an egregious and destructive manner. ${ }^{5}$ The lack of trust in financial services providers may explain why many pensioners have chosen not to trust in market solutions after the FCA introduced rules liberalising pension choices, allowing full withdrawals of pension pots. ${ }^{6}$ Organised consumer bodies such as Which the consumer group and the Citizen's Advice service have also taken advantage of new rights introduced since 2012, to bring 'super-complaints' ${ }^{7}$ before the FCA in order to investigate sub-optimal conduct or market failures in financial services. The FCA has also intensively pursued thematic studies to gather evidence and consider policy reform in various areas, including high cost credit, ${ }^{8}$ mortgage markets ${ }^{9}$ such as interest-only mortgages, ${ }^{10}$ unsecured lending, ${ }^{11}$ and annuity sales. ${ }^{12}$ Against the contextual mosaic of concerns and flaws in a variety of consumer finance markets, could the introduction of a 'duty of care' on the part of financial services providers articulate a pathway to steer conduct, facilitate more optimal outcomes, and restore consumer understanding and expectations so that trust can be rebuilt in their engagement with the financial services markets as a whole? The FCA's consultation is not a unique initiative in terms of taking stock of the 'state of the nation' in the financial services sector and inquiring into policy and reform.

\footnotetext{
2 FCA, Discussion Paper on a Duty of Care and Potential Alternative Approaches (July 2018).

${ }^{3}$ See Eilis Ferran, 'Regulatory Lessons from the Payment Protection Insurance Mis-Selling Scandal in the UK' (2012) European Business Organisation Law Review 248.

${ }^{4}$ The products became overly costly in a decreasing interest rate environment after the global financial crisis, but it would often be exorbitant to terminate the agreements before maturity, see for example Crestsign Ltd $v$ Natwest and RBS [2014] EWHC 3043 (Ch); Thornbridge Limited v Barclays Bank Plc [2015] EWHC 3430 (QB); and FCA, Review of Interest Rate Hedging Products (2016) at https://www.fca.org.uk/consumers/interest-ratehedging-products.

${ }^{5} \mathrm{FCA}$, Statement on the Financial Conduct Authority's Further Investigative Steps in relation to RBS GRG (July 2018).

${ }^{6}$ FCA, Retirement Outcomes Review (June 2018) at https://www.fca.org.uk/publication/market-studies/ms161-3.pdf, paras 1.7-8.

${ }^{7}$ Which super-complaint on push payments in 2016, see https://www.fca.org.uk/news/statements/updatewhich-super-complaint-push-payments; the Citizen's Advice's super-complaint on insurers' discriminatory treatment of existing customers as compared to new customers in Sep 2018, see https://www.fca.org.uk/news/statements/super-complaint-citizens-advice-cma-excessive-prices-disengagedconsumers.

${ }^{8}$ FCA, Outcome of High Cost Credit Review (May 2018) at https://www.fca.org.uk/news/press-releases/fcapublishes-outcome-high-cost-credit-review.

${ }^{9}$ FCA, Mortgages Market Study: Interim Report (May 2018) at https://www.fca.org.uk/publication/marketstudies/ms16-2-2-interim-report.pdf.

${ }^{10}$ FCA, The Fair Treatment of Existing Interest-Only Mortgage Customers (Jan 2018) at https://www.fca.org.uk/publications/thematic-reviews/tr18-1-fair-treatment-existing-interest-only-mortgagecustomers.

${ }^{11}$ FCA, Thematic Review: Early Arrears Management in Unsecured Lending (Dec 2016) at https://www.fca.org.uk/publication/thematic-reviews/tr16-10.pdf.

12 FCA, Thematic Review: Review of Annuity Sales Practices (Feb 2017) at https://www.fca.org.uk/publications/thematic-reviews/review-annuity-sales-practices.
} 
Following a stream of mis-selling problems the Australian Royal Commission is undertaking a broadranging fundamental review of financial services sector conduct in Australia relating to credit, superannuation products, investment and advice markets. ${ }^{13}$

This article argues that what the FCA is seeking to address is quite clearly not to be answered by the introduction of a 'duty of care' or a 'fiduciary duty'. Section A explains why the legal baggage in the common law duty of care and the equitable fiduciary duty do not render these legal concepts suitable for addressing the FCA's policy concerns. Section B then articulates the real question that the FCA is asking, which is what gaps there are in the current regulatory regime that need to be plugged. The Section argues that there are four areas of gaps, namely in the scope of customer protection, the standards of protection, enforcement by the FCA and customer redress mechanisms. More complex policy thinking is warranted than simply reliance on a 'duty of care'. Section C provides concluding thoughts on policy choices for the FCA.

\section{A. Why the 'Duty of Care' is Not the Answer}

The 'duty of care' seems to promise in a shorthand all the benefits of the legal tradition and interpretation that are imbued in it. However, as the 'duty of care' is fundamentally a legal concept, it has to be unpacked within that framework in order to ascertain what it offers for financial services customers. We argue that the adoption of a statutory 'duty of care' by the FCA cannot and should not mean something entirely different from the common law 'baggage' that it carries, or else this will cause immense legal uncertainty and confusion for legal practitioners who are at the forefront of advising financial services providers. The adoption of a statutory 'duty of care' must import the common law jurisprudential development of this duty, or it is meaningless to consider the utility of such an adoption in a vacuum.

The common law duty of care is nowadays raised in private litigation largely as a fall-back if claimants are not able to benefit from the protection of regulatory duties. ${ }^{14}$ This could be due to claimants being of the category that do not enjoy the highest levels of protection under regulatory duties, ${ }^{15}$ and/or that claimants are unable to pursue a private action in breach of regulatory duties as they are not 'private persons' within the meaning of section 138D of the Financial Services and Markets $\mathrm{Act}^{16}$ that entitle them to bring such an action.

\section{Can a Duty of Care Fill Gaps in Regulatory Duties?}

Under regulatory rules, financial customers have to be categorised as one of three categories: 'retail customer', 'professional customer' or 'eligible counterparty'. ${ }^{17}$ Eligible counterparties are usually financial institutions or large corporations that choose to be so categorised, who can deal

\footnotetext{
${ }^{13}$ Royal Commission into Misconduct in the Banking, Superannuation and Financial Services Industry (28 Sep 2018) at https://financialservices.royalcommission.gov.au/Documents/interim-report/interim-report-volume1.pdf.

${ }^{14}$ Eg Thornbridge Limited v Barclays Bank PIc [2015] EWHC 3430 (QB); Crestsign Ltd v National Westminster Bank plc and Royal Bank of Scotland plc [2014] EWHC 3043 (Ch), a number of cases involving similar transactions as in these cases will be discussed shortly.

${ }^{15}$ See discussion below.

${ }^{16}$ Grant Estates Limited (In Liquidation); Ruari Stephen; and Jamie Stephen v The Royal Bank of Scotland Plc, Thomas Campbell Maclennan, Kenneth Robert Craig, Joint Administrators of Grant Estates Limited [2012] CSOH 133; MTR Bailey Trading Ltd v Barclays [2015] EWCA Civ 667.

17 See Arts 25, Markets in Financial Instruments Directive 2014/65/EU; Art 45, Commission Delegated Regulation (EU) 2017/565 of 25 April 2016 above, directly applicable to the UK.
} 
confidently at arms-length with financial services providers. ${ }^{18}$ Professional customers include those same financial and corporate institutions mentioned above as well as incorporated and unincorporated undertakings and trusts above a certain threshold of assets, and experienced, sophisticated or high net-worth individuals who choose to be so categorised. ${ }^{19}$ These customers are not as well-protected as 'retail customers', who are defined as any customer not a professional customer or eligible counterparty. ${ }^{20}$ For advisory and portfolio management services, financial services providers have to ensure that their service or advice is 'suitable' for the customer, ${ }^{21}$ but retail customers benefit from a more comprehensive information collection exercise than other customers and the obligation of 'suitability' is more extensively owed to retail customers. ${ }^{22}$ Financial services providers are entitled to assume that per se professional clients and eligible counterparties have the necessary knowledge and understanding of the engagement and are financially able to bear risk, although such an assumption is narrowed to the client's knowledge and understanding where an elective professional client is concerned. ${ }^{23}$ In relation to other financial transactions, financial services providers owe a duty to ensure that such transaction is 'appropriate' for customers, meaning that the customer understands the nature of such a transaction. ${ }^{24}$ The assumption of knowledge is however applied to professional customers, ${ }^{25}$ so in reality, financial services providers would deal only at arms-length with such customers.

Under regulatory rules, professional customers and eligible counterparties are entitled to lesser levels of customer protection but that is often a trade-off for opportunities to engage in higher risk but possibly higher return financial products. ${ }^{26}$ Further, in dealing with professional customers or eligible counterparties, financial services providers often frame their relationships with such customers as 'execution-only', ${ }^{27}$ meaning that they act as intermediaries only to purchase or sell customers' financial interests and the customers remain fully in control of their financial decisionmaking. ${ }^{28}$ However, the FCA does provide that in all dealings with customers, financial services

\footnotetext{
${ }^{18}$ See FCA Handbook COBS 3.6.

${ }^{19}$ See FCA Handbook COBS 3.5.

${ }^{20}$ FCA Handbook COBS 3.4.

21 'Suitability' is interpreted as meeting the client's investment objectives and risk tolerance, and that the client understands the nature of the product or service engaged with and is financially able to bear those risks. For a retail customer, the financial services provider must be satisfied that all three elements are achieved and explained in a suitability report to the customer. See Art 54, Commission Delegated Regulation (EU) 2017/565 of 25 April 2016 supplementing Directive 2014/65/EU of the European Parliament and of the Council as regards organisational requirements and operating conditions for investment firms and defined terms for the purposes of that Directive, directly applicable to the UK.

${ }^{22}$ Above.

${ }^{23}$ Art 54, Commission Delegated Regulation (EU) 2017/565 of 25 April 2016 above, directly applicable to the UK, and supplemented by COBS 9.

${ }^{24}$ Art 56, Commission Delegated Regulation (EU) 2017/565 of 25 April 2016 above, directly applicable to the UK.

${ }^{25}$ Above.

${ }^{26}$ Customers may challenge the classification especially after losses have been sustained on their riskier ventures, such as in Bank Leumi (UK) PLC v Linda Joy Wachner [2011] EWHC 656 (Comm), but courts have upheld firms' classifications as long as these have been achieved with proper processes.

${ }^{27}$ Eg Cassa di Risparmio della Repubblica di San Marino SpA v Barclays Bank Ltd [2011] EWHC 484 (Comm).

${ }^{28}$ See extensive discussion in Danny Busch, 'MiFID II: Stricter Conduct of Business Rules for Investment Firms' (2017) 12 CMLJ 340 in relation to the introduction of enhanced customer protection under MiFID 2014 that recategorises transactions previously regarded as trading with the firm as a counterparty and hence unprotected to being intermediated transactions.
} 
providers need to ensure that their communications are 'fair, clear and not misleading', ${ }^{29}$ and this seems to be the baseline level of regulatory protection for customers even in unprotected execution-only transactions. Specific communications duties have been augmented by the European Commission Regulation in $2017^{30}$ that requires precise matters to be disclosed, such as risks and benefits in a balanced manner, impediments to divestment, price volatility, appropriate warnings and all costs and charges imposed by the firm and associated parties. ${ }^{31}$ These requirements may go some way towards mitigating the thin level of protection that professional clients enjoy in relation to advisory and other transactional contexts.

The common law duty of care is often asserted in order to test the scope and standards of protection for customers who do not clearly benefit from the scopes of regulatory protection discussed above. This has occurred in relation to a series of litigation involving interest-rate hedging products sold by banks to small businesses, which are classified as 'professional customers', and often sold on an 'execution-only' basis. Interest-rate hedging products allow small businesses that already borrow from their banks to swap a floating interest rate on their borrowing for a fixed one, in order to hedge against risks of interest rate or in one case, foreign currency fluctuations. However, after the Bank of England reduced interest rates to unprecedented lows after the global financial crisis 2007-9, it became too insensibly expensive to carry on with the hedging products. Nevertheless, many small businesses could not terminate the arrangements unless they paid an exorbitant break fee. This series of litigation resulted in mixed jurisprudence for the duty of care on the part of financial services providers, largely because of different facts in each case. Small business customers, who lie at the border of retail and professional categories provide a key context for testing the scope and standards of protection that financial services customers are offered by law and policy.

First, no challenge was made in any of the small business litigation cases in relation to client classification. The apparent consensus in accepting that they were professional customers may lie in customers' implicit acceptance that they would unlikely have access to products such as the interestrate swap if they were not so classified. The courts accepted that the products were sold as execution-only ${ }^{32}$ and the regulatory duty of appropriateness (not suitability, as that applied only to investment advice and portfolio management) was not attracted. It may be argued that small businesses, who may not be really sophisticated and lie at the borderline between retail and professional classifications, would be surprised to find that the regulatory regime is scaled back significantly in protecting them in their dealings with financial services providers. The regulatory regime in essence provides the deepest extent of protection to retail customers who are likely to access less complex products. Even if such a position is proportionate in relation to retail customers whose capabilities, knowledge and experience are in the poorest category of the three, there is a lack of policy thinking in relation to whether the complexity and riskiness of financial products should affect the scope and extent of regulatory protection, in the higher groups of customer classifications.

\footnotetext{
${ }^{29}$ FCA Handbook COBS 4.1.1, 4.2, also Piers Reynolds and Anthony Collins, 'Non-advised Sales of Financial Products: An End to Caveat Emptor?' (2018) JIBLR 148.

${ }^{30}$ Commission Delegated Regulation 2017/565/EU, above.

${ }^{31}$ Arts 46-50, esp Art 48.

32 Titan Steel Wheels Ltd v Royal Bank of Scotland plc. [2010] EWHC 211; Grant Estates, above; Green and another v Royal Bank of Scotland plc (Financial Conduct Authority intervening) [2013] EWCA Civ 1197; Thornbridge, above.
} 
It could be argued that as a baseline in regulatory protection, customers could be expected to be given information in a 'fair, clear and not misleading' manner by financial services providers. ${ }^{33}$ In the case of the small businesses that purchased interest rate swaps, the imbalance of information provided to them in case of adverse scenarios or risks and the often undisclosed high levels of break fees could have changed their minds. These claimants could have sought protection under 'communication-based' regulatory duties if higher levels of protection under suitability or appropriateness cannot be obtained. However, even if communications duties could in theory afford some protection, especially since they have been augmented by the European Commission delegated regulation in 2017, such protection is only ex ante in nature. Claimants face obstacles in ex post enforcement as there is a bar against litigants that are not 'private persons' under section 138D of the Financial Services and Markets Act. ${ }^{34}$ The right to bring civil proceedings in respect of a breach of statutory duty by a financial services provider is only afforded to 'private persons', due to a legacy policy position of wishing to prevent firms from taking opportunistic and excessive litigation. ${ }^{35}$ Small businesses could be relatively unsophisticated like private persons and subject to harms that they would regard as 'consumer harms', but they are unable to avail themselves of regulatory protection with such a circumscribed private litigation regime. ${ }^{36}$

Would the common law duty of care be able to compensate for the shortfalls of coverage by the regulatory regime such as in the above cases? We argue that case law has not charted such a path, and we set out our findings below. In sum, where the common law duty of care has been tested in aspects reflecting shortfalls of the regulatory regime, it has not advanced clear and superior solutions. Section B proposes that imperfections in consumer protection ought to be dealt as reforms to the regulatory regime in more precise and well-articulated ways than suggested in the FCA's consultation.

We survey the case law jurisprudence on the common law duty of care and highlight the recent series of small business litigation against banks where regulatory protections did not apply. These cases put to the test what the common law exclusively offers to financial customers.

\section{Exclusion of Duty of Care}

(a) A common law duty of care can arise as a separate legal duty between financial services providers and their customers, as being not coterminous with regulatory duties. ${ }^{37}$ This depends on whether the financial services provider assumes responsibility for the customer's financial decision-making in a relationship of proximity. ${ }^{38}$ Case law has demonstrated that the same factual circumstances that frame the transaction as 'executiononly' by financial services providers often also result in the court's finding that responsibility has not been assumed by the financial services provider. This is because there are often

\footnotetext{
${ }^{33}$ FCA Handbook COBS 4.2.

${ }^{34}$ Grant Estates, above; MTR Bailey, above.

35 Discussed in Grant Estates, above; Shazia Khan Afghan, 'What is the Purpose of Section 138D of the FSMA 2000 (as amended)?' (2018) 33 Journal of International Banking Law and Regulation 163.

${ }^{36}$ Afghan, above.

${ }^{37}$ Green and another v Royal Bank of Scotland plc (Financial Conduct Authority intervening) [2013] EWCA Civ 1197, and earlier, Seymour v Ockwell [2005] EWHC 1137 and Jenny Hamilton, 'Negligence in the Corridor? The Interaction Between "Separate Rooms" of Regulation and the Common Law in Financial Services' (2007) Professional Negligence 134 on the lack of coherence between the body of regulatory law and civil obligations. ${ }^{38}$ Based on Hedley Byrne \& Co Ltd v Heller \& Partners Ltd (1964) AC 465 (HL). Discussed in Grant Estates, above.
} 
clear contractual terms stating the 'execution-only' nature of the transaction and clients' attention are often drawn to these and relevant disclaimers. ${ }^{39}$

(b) In cases where an advisory duty of care is expressly excluded between sophisticated parties and their financial services providers, courts have tended to uphold this, ${ }^{40}$ as it is likely that such exclusion would not be held to be unreasonable under the Unfair Contract Terms Act $1977^{41}$ and contractual estoppel would work against the claimant. ${ }^{42}$

\section{Limited Assumption of Responsibility in the Financial Transaction}

(c) It may be argued that where a common law advisory or 'Hedley Byrne' duty does not apply or is validly excluded, financial services providers still owe a common law baseline duty not to mislead or misstate. This duty is limited in nature and does not extend to providing customers with comprehensive information or to 'educate' the customer in relation to the product. ${ }^{43}$ However, as financial services providers may be asked to explain product features and consequences, the possibility has been raised that in such communications, a slightly wider informational duty than the 'duty not to misstate' could exist. A 'mezzanine' duty ${ }^{44}$ to inform fully, accurately and properly what is asked has been mooted, in particular in relation to break fees for the interest-rate hedging product in question. Often in these cases the full extent of break fees are not disclosed but only indicative suggestions are made. If claimants could make a case based on a breach of duty with regard to communications, the door to redress could be open. However, the Court of Appeal has firmly denounced the characterisation of a 'mezzanine' duty, insisting the conduct of communication is governed by the same Hedley Byrne duty in relation to assumption of responsibility.$^{45}$ If financial services providers are found on the facts to have assumed responsibility in providing an extent of information, then such information should be provided fully, accurately and properly. No breach of such duty has been found in the small business series of litigation, and that should be of no surprise as banks are able to produce aptly worded documentation that pass the test. In an exceptional case, ${ }^{46}$ the bank's own commitment to a high level of communication to give the customer a 'balanced view' in relation to every financial product sold (even in an execution-only context), was held binding on the bank to discharge such a

\footnotetext{
${ }^{39}$ Grant Estates, above and Green and another v Royal Bank of Scotland plc (Financial Conduct Authority intervening) [2013] EWCA Civ 1197.

40 JP Morgan Chase Bank (formerly known as The Chase Manhattan Bank) (a body corporate) and Others v Springwell Navigation Corporation (a body corporate) and by Counterclaim Springwell Navigation Corporation (a body corporate) v JP Morgan Chase Bank (formerly known as The Chase Manhattan Bank) (a body corporate) and Others [2008] EWHC 1186 (Comm), also discussed critically in Christa Band, 'Selling Complex Financial Products to Sophisticated Clients: JP Morgan Chase v Springwell: Part 1' (2009) 24 JIBLR 71; Murphy v HSBC Bank plc [2004] All ER (D) 211.

${ }^{41}$ See Titan Steel Wheels $L t d$, above in the context of parties with perceived equality in bargaining power.

42 Thornbridge, above where a context of equality in bargaining power was perceived by the court.

${ }^{43}$ Crestsign Ltd v Natwest and RBS [2014] EWHC 3043 (Ch).

${ }^{44}$ Above, Marz Ltd v Royal Bank of Scotland plc [2017] EWHC 3618 (Ch) and discussed with approval in Piers Reynolds and Anthony Collins, 'Non-advised Sales of Financial Products: An End to Caveat Emptor?' (2018) JIBLR 148; Victoria Stace, 'Mis-selling Financial Products: When Can the Customer Claim in Negligence?' (2016) JBL 517.

45 Property Alliance Group Ltd v Royal Bank of Scotland [2018] EWCA Civ 355.

${ }^{46}$ Philip Thomas \& anr v Triodos Bank NV [2017] EWHC 314 (QB).
} 
duty. This case could however be regarded as exceptional as the duty to inform has become contractually shaped rather than shaped as a matter of general civil obligations.

\section{Lack of Appetite for More Pronounced Judicial Activism}

(d) Where common law duties are the only fall-back for financial customers, they have achieved limited results for aggrieved customers, who need to bear their own losses in a transactional environment that is usually determined to be at arms-length and based on caveat emptor. Even where common law duties are determined to arise, case law has adopted the approach of pitching the standard of care according to what regulatory duties demand, as regulatory duties afford good evidence of what is reasonably expected to discharge a duty of care. ${ }^{47}$ This 'dovetailing' approach limits the potential of common law duties to address imperfections or to supplement the regulatory regime. ${ }^{48}$ Judges frown upon common law actions being used to circumvent the regulatory scope or standards ${ }^{49}$ Indeed any attempt to infer a common law duty based on regulatory duties (which do not apply to the claimant based on the reasons discussed above) is doomed to fail. ${ }^{50}$ There is no appetite for judicial activism to be perceived as running counter to established policy in financial services regulation. This approach may be contrasted with discussions at the EU level in relation to how both European and private law are needed to address financial customer protection that regulatory rules fail to address. ${ }^{51}$

\section{Failure to Establish Causation}

(e) Finally, even if a breach of common law (or regulatory duty) is found, courts can find that there is a lack of causation therefore defeating the claimant's hope of securing compensation for financial losses. Where courts find based on the facts that claimants would still have purchased the financial products they did,,$^{52}$ even if better informed or advised, only nominal damages would be awarded.

The utility of the common law 'duty of care' has been tested in a context where regulatory duties do not apply, and as far as the unsuccessful claimants (which are the majority in this series of litigation) are concerned, it is limited. The assertion and enforcement of a duty of care on the part of financial services providers is fundamentally based on a narrative of transactional bilateralism between parties, hence the judicial examination of whether the financial services provider 'assumes responsibility' over the customer causing his/her detriment. The examination is based on transactional facts despite the reality that financial services providers are in a position to construct the transactional context in a way most favourable to them. The private enforcement of a duty of

\footnotetext{
47 Seymour v Ockwell, above; David Anderson v Openwork Limited 2015 WL 3795707.

48 Indeed commentators have argued that the regulatory regime clearly affords more financial consumer protection than under general law, see Christa Band and Karen Anderson, 'Selling Complex Financial Products to Sophisticated Clients: JP Morgan Chase v Springwell: Part 2' (2009) 24 JIBLR 233.

${ }^{49}$ Grant Estates, above.

${ }^{50}$ Green and Anor, above.

${ }^{51}$ Guido Comparato, 'The Design of Consumer and Mortgage Credit Law in the European System' in Hans W Micklitz and Irina Domurath (eds), Consumer Debt and Social Exclusion in Europe (Surrey: Ashgate, 2015) at ch2; Hans W Micklitz, 'Conclusions: Consumer Over-indebtedness and Consumer Insolvency: From Micro to Macro' in Hans W Micklitz and Irina Domurath (eds), Consumer Debt and Social Exclusion in Europe (Surrey: Ashgate, 2015) at ch13 referring to the possible impact of the CJEU's preliminary ruling in Mohamed Aziz $v$ Caixa d'Estalvis de Catalunya, Tarragona i Manresa (Catalunyacaixa) Case C 415/11, 14 March 2013.

52 Beary v Pall Mall Investments [2005] EWCA CIV 415; Zaki \& Ors v Credit Suisse UK Ltd [2013] EWCA 14.
} 
care is also ex post in nature, focusing on the transactional and bilateral justice in the case before the court and cannot address (a) the question of normative conduct or 'what is rightly expected' in relation to financial providers' behaviour, which is a question of an ex ante nature or (b) the wider distributional justice issues in relation to financial risks and outcomes. The judiciary seems not to be prepared to engage in activism over broader issues in financial conduct and distributional justice in an area perceived to be comprehensively governed by regulation.

In considering the shortcomings of existing regulatory protection for financial customers, especially consumers, these should be appraised in a systematic manner. Broad brush impressions such as preferring 'general' over 'specific' duties or 'English law versus European Directive duties' are likely to be unhelpful.

Specific duties such as suitability or appropriateness which are the product of European Directives ${ }^{53}$ may be seen to hail from a civil code tradition. However this is a misperception. A legal concept such as 'suitability' is not alien to this or other common law jurisdictions. 'Suitability' has been adopted as the standard for financial advice by the Securities Investments Board, ${ }^{54}$ the predecessor of the Financial Services Authority. ${ }^{55}$ It has also been applied to investment advisors and broker-dealers in the United States. ${ }^{56}$ The development of financial services regulation at the EU level is a unique amalgam forged with insights from common law and civil law jurisdictions, ${ }^{57}$ and regulatory duties imposed under the Markets in Financial Instruments Directive are regarded as a body of law with distinct character not necessarily biased towards the civil law tradition. ${ }^{58}$ Indeed legal academics and practitioners from civil law jurisdictions in the EU also grapple with reconciling regulatory duties with their pre-existing fabric of civil obligations, and different jurisdictions have taken different approaches. ${ }^{59}$

Further, a myth that needs to be dispelled with regard to the common law duty of care is that it does not import of a 'fiduciary nature' or a duty of 'best interests' that has been articulated and interpreted in the United States and Australia respectively. That is not to say that those levels of protection are undesirable, quite the opposite, as the FCA's consultation reflects social expectations and appetite for a 'higher' level of protection than offered under the existing regulatory regime.

\footnotetext{
${ }^{53}$ Markets in Financial Instruments Directive 2004, then recast into the Directive 2014/65/EU.

54 The Financial Services (Conduct of Business) Rules 1991, Release 106, rule 5.01 for example.

${ }^{55}$ Which was reformed in 2012 after the single regulatory structure was dismantled in the UK after the global financial crisis 2007-9. See Financial Services Act 2012.

56 See discussion later.

${ }^{57}$ The process of law-making in financial services regulation is based on well-represented comitology at the European Commission and coordinated decision-making at the level of the relevant agency ie the European Banking Authority, European Securities and Markets Authority or the European Insurance and Occupational Pensions Authority which feature full national representations to each Authority's Board, culminating in the co-decision procedure between Parliament and Council. Input representation and legitimacy has characterised EU level law-making, see generally, Niamh Moloney, "The Lamfalussy Legislative Model: A New Era For The EC Securities and Investment Services Regime" (2003) 52 International and Comparative Law Quarterly 499; "EU Financial Market Regulation After the Global Financial Crisis: More Europe or More Risks?” (2010) 47 Common Market Law Review 1317.

${ }^{58}$ Danny Busch and Cees van Dam (eds), A Bank's Duty of Care (Oxford: Hart Publishing, 2017) which contains comparative discussions of the relationship between civil law and regulatory law duties under MiFID as applied in a number of EU jurisdictions; Danny Busch, 'Why MiFID Matters to Private Law-The Example of MiFID's Impact on an Asset Manager's Civil Liability' (2012) 7 CMLJ 386.

${ }^{59}$ Above.
} 
There are two points to be made. First, the Australian 'duty of best interests' ${ }^{60}$ is a statutory but 'general duty'. It is not very dissimilar from the existing regulatory duty of 'suitability' but goes somewhat further than our position. There is a case for considering if such a duty would serve the purposes of the FCA's reform considerations. Second, the 'fiduciary' duty articulated for US investment advisers is interpreted differently from the meaning of 'fiduciary' under English Law. It is not advisable to import and transplant this concept into regulatory duties, as the transplantation of a concept that is already interpreted differently under English law is apt to cause confusion. Legal transplantations are often reinterpreted in order not to create disjunctions with existing law and social culture, ${ }^{61}$ and we argue that given our fabric of fiduciary law, it is inappropriate to adopt the fiduciary duty applicable to US investment advisers, although it substantively chimes with some of the expectations underlying the FCA's reform considerations.

\section{Duty of Best Interests}

The FCA consultation has been largely driven by the Financial Services consumer panel, a stakeholder panel to the FCA which argues that the customer-facing conduct on the part of financial services providers needs to be elevated to a duty that incorporates treating customers honestly, fairly and professionally in customers' best interests. ${ }^{62}$ This objective is regarded as incorporated within a 'duty of care' and is insufficiently met by the FCA's general principle of 'treating customers fairly' which is one of the bedrock principles ${ }^{63}$ for more specific regulatory duties such as in communications or advice.

We have earlier explained why the legal conception of the 'duty of care' should not be rehashed in regulatory formulation and is unlikely to address the Panel's concerns. We note that the EU Markets in Financial Instruments Directive 2014 has enacted a general duty of best interests in the section that deals with firms' general conduct of business ${ }^{64}$ Although 'overarching' in nature, Busch ${ }^{65}$ argues that the 'umbrella' nature of the duty would likely be interpreted according to its specific elements in the legislation dealing with particular conduct, ie information communications, advice, execution, order handling, managing conflicts of interest, inducements and obligations to record telephone conversations and electronic communications. In this light, the FCA's consultation on a 'duty of care' may genuinely represent an inquiry into introducing a new general duty different from the MiFID 'duty of best interests'.

We look to the Australian 'duty of best interests' for financial service providers and argue that it may go some way towards meeting the Panel's demands. As Australia is a common law jurisdiction, we see the introduction of this duty as a deliberate framing in policy to introduce a broad legal formulation in different terms from the concepts in general law.

\footnotetext{
${ }^{60}$ S961B, Corporations Act 2001 as amended. This is discussed shortly.

${ }^{61}$ E Örücü, 'Law as Transposition' (2002) 52 ICLQ 206-7; M Langer, 'From Legal Transplants to Legal Translations' (2004) 45 HJIL 1, Mindy Chen-Wishart, 'Legal Transplant of Undue Influence: Lost in Translation or a Working Misunderstanding?' (2013) 62 ICLQ 1; Pierre Legrand, 'The Impossibility of Legal Transplants' (1997) 4 Maastricht Journal of European and Comparative Law 111.

${ }^{62}$ This position has been championed since 2015, see Financial Services Consumer Panel, 'Incorporating a Duty of Care into the Financial Services \& Markets Act' (June 2015) at https://www.fscp.org.uk/sites/default/files/fscp position paper on duty of care 2015.pdf.

${ }^{63}$ FCA Handbook PRIN 2.1.1, Principle 6. The bedrock nature of the principles in the PRIN chapter is affirmed in British Bankers' Association (BBA)) v Financial Services Authority (FSA) [2011] EWHC 999.

${ }^{64} \operatorname{Art} 24(1)$.

${ }^{65}$ Danny Busch, 'MiFID II: Stricter Conduct of Business Rules for Investment Firms' (2017) 12 CML 340.
} 
Where personal advice is provided, a duty of best interests is attracted ${ }^{66}$ This duty includes: ${ }^{67}$

(a) identifying customers' objectives, financial capabilities,

(b) ensuring that advice is explicitly or implicitly sought,

(c) making reasonable inquiries to 'complete' an informational profile of the customer;

(d) conducting reasonable diligence into a range of financial products that meet the information profile

(e) making all judgments in rendering the advice based on the customer's relevant circumstances, and

(f) taking any other reasonable step to ensure that the customer's best interests are met.

The provider must then, after taking the procedural steps above, ${ }^{68}$ reasonably conclude that the resulting advice is appropriate for the customer.$^{69}$ Based on the procedural steps (a) to (e), it is arguable that the duty of best interests goes further than the regulatory duty of suitability under the same context of personal advice or 'recommendation'. ${ }^{70}$ The 'suitability' duty does indeed include information gathering of a similar nature and ensuring that advice rendered is based on the relevant information that is obtained. ${ }^{71}$ However, our 'suitability' duty does not include reasonable due diligence in surveying a range of possible products. This is because an 'independent financial adviser' is required to do so, ${ }^{72}$ and a 'restricted' adviser who is tied to a range of products would be able to let a customer know up front of his/her restricted position. ${ }^{73}$ The Australian Securities and Investments Commission (ASIC) has clarified that due diligence can extend beyond a restricted adviser's list of products where other products are better suited or where clients request. ${ }^{74}$ In this manner, the procedural expectations of a financial advice provider in Australia are more extensive than under our duty of suitability. However there is broad similarity in terms of the ex ante procedural approach in governing the decision-making process of financial advice providers.

ASIC has also clarified that the duty of best interests' includes ensuring that advice is fit for its purpose, ie relevant to customer's circumstances and would put the customer in a better position than without the advised course of action. ${ }^{75}$ Does this mean that financial services providers take some sense of responsibility for the outcomes of financial products recommended to customers? This is important as financial products are 'credence goods' whose performance is not usually known until after a certain time period has elapsed, making it difficult for customers to assess quality on an ex ante basis. Although the expectations such as articulated by the Financial Services Consumer

\footnotetext{
${ }^{66}$ S766B, s961B, Corporations Act 2001 as amended.

67 Paraphrased by us.

${ }^{68}$ The procedural steps are mandatory and failure of those steps may attract ASIC enforcement as a proxy for failure in rendering advice in customers' best interests, see ASIC v NSG Service Pty Ltd [2017] SCA 345.

69 S961G, Corporations Act 2001 as amended.

${ }^{70}$ Art 9, Commission Delegated Regulation (EU) 2017/565 of 25 April 2016 supplementing MiFID of the European Parliament and of the Council as regards organisational requirements and operating conditions for investment firms and defined terms for the purposes of that Directive and Article 53(1C) and 53(1D) of the Regulated Activities Order.

${ }^{71}$ See $\mathrm{n} 21$.

72 FCA Handbook COBS 6.2B.11, 17, 18.

${ }^{73}$ FCA Handbook CONS 6.2B.33.

74 Para 67, ASIC, Future of Financial Advice: Best interests Duty and Related Obligations (Dec 2012).

${ }^{75}$ Above, paras 57-70.
} 
Panel do not expect financial services providers to promise certain outcomes or become liable for them in the natural course of things, efforts taken to connect customers with products that can reasonably be said to achieve 'a better position' could minimise poor outcomes in the future, even if outcomes are inherently uncertain. Australian case law ${ }^{76}$ has clarified that the duty of best interests does not require that certain outcomes be met, and that 'better position' is part of the ex ante assessment made by the financial adviser in his/her procedural steps. We see traction in the 'better position' assessment as a focus for the duty of best interests, as financial services providers would have to be able to explain on a net basis, the benefits and drawbacks (or risks), the contours or impressions of a 'better position', even if the latter cannot be accurately predicted. In this manner the Australian duty of best interests goes further than 'suitability', although they share similar ex ante, information-based and procedural approaches. The efforts expected to be expended by a financial services provider subject to the Australian duty of best interests seem more extensive in relation to due diligence and the quality of advice at the point of sale.

Further, ASIC also imposes the 'better position' standard in relation to basic banking and general insurance products even if the procedural steps required for the advisor are relatively more limited than discussed above. This ensures that there is an adequate baseline level of protection even for relatively non-complex products for consumers. ${ }^{77}$

Afghan ${ }^{78}$ argues that there is a lacuna in existing regulatory law, i.e. investment advisers are not under a duty to recommend the 'best product available' as long as what is recommended is 'suitable'. The duty of suitability is discharged if the product recommended meets the three criteria of suitability, i.e. meeting the customer's investment objectives and risk tolerance, is capable of being understood by the customer, and that the financial risks relating to the product can be borne by the customer. ${ }^{79} \mathrm{~A}$ 'suitable' product is not necessarily the 'best product' available, ${ }^{80}$ bearing in mind that existing regulatory law does not impose an across-the-board duty of diligence in surveying the market. The Australian 'duty of best interests' does not explicitly require a 'best product' advice standard but comes closer to it, as reasonable due diligence is expected of both independent and restricted advisers to slightly different extents, and it is arguable that the burden could be put on an adviser to defend a particular advice that is not the 'best advice'. This brings us to look back at the superseded standard of 'best advice' that prevailed in the UK financial services industry before the era of the Financial Services Authority.

Duties generated by self-regulatory organisations for the financial sector (such as LAUTRO ${ }^{81}$ ) were framed in terms of 'best advice', being of a more specific nature than the common law duty of care..$^{82}$ This standard was also adopted by the Securities Investments Board which supervised financial sector self-regulatory organisations and introduced certain standardisations in conduct of business rules. ${ }^{83}$ 'Best advice' required independent financial advisers to provide the 'best advice'

\footnotetext{
${ }^{76}$ ASIC v NSG Service Pty Ltd [2017] SCA 345.

77 Paras 68-70 ASIC, Future of Financial Advice, above.

78 Shazia Khan Afghan, 'Should Banks Owe a Statutory Duty of Care to Their Customers in the UK?' (2017) JIBLR 494.

${ }^{79}$ See $\mathrm{n} 21$.

${ }^{80}$ Afghan's discussion of O'Hare \& O'Hare v Coutts \& Co [2016] EWHC 2224 (QB), above.

${ }^{81}$ Life Assurance and Unit Trust Regulatory Organisation, one of the half a dozen or so self-regulatory bodies undertaking financial services regulation under the Financial Services Act 1986.

82 For example see David Nicholls, "Ensuring Sales Forces Provide Best Advice"(1993) 2 Journal of Financial

Regulation and Compliance 42-47; Kit Jebens, 'LAUTRO -A Pioneering Regulator 1986-1994' (1997).

83 see rules 5.01, 5.02, Financial Services (Conduct of Business) Rules 1991, Release 106.
} 
out of the products surveyed in the whole of the market, and restricted advisers to provide the "best advice' within the range of financial products $s /$ he was tied to. The 'best advice' standard also shaped the interpretation of the duty of care owed by the personal financial adviser in the case of Gorham v British Telecommunications PIc. ${ }^{84}$ This case considered if the personal pension product purchased was in breach of the duty of care. As the personal pension product did not provide as extensively as the individual's occupational pension product in case of death for his dependent family, the adviser was held to be in breach of the duty of care for failure to ensure best advice, ${ }^{85}$ which was the regulatory/self-regulatory standard at that time that informed the standard under general law. It would seem that this standard is arguably superseded in the modern interpretation of the duty of care reflecting the current regulatory standard of suitability, ${ }^{86}$ which would appear to achieve less extensive protection than under a 'best advice' standard.

On a spectrum of customer protection, the Australian duty of best interests and the duty of best advice appear to offer customers a more extensive standard of protection above what seems to be offered under the standard of suitability. Hence the FCA needs to clearly ascertain the level of protection as a matter of policy, before committing to any particular shorthand duty in general terms. Further, it is important to determine if a duty of best interests or 'best product/service' should apply to other services and transactions that are not in an investment advisory context, as 'suitability' currently applies only to the provision of investment advice and portfolio management, and other services are judged according to the standard of 'appropriateness' ${ }^{87}$ or 'best execution' ${ }^{88}$ It needs to be determined as a matter of policy whether apart from the investment advice context there are also shortfalls in the regulatory regime governing other services and transactions, and if so, whether such shortfalls should be addressed by a general standard applying across the board to financial services, or be elevated in different and more specific terms depending on the nature of the service/s. This question is especially pertinent in the light of the series of small business litigation discussed above, as their transactions have been framed in a non-advisory context.

\section{US Fiduciary Duty}

Investment advisers in the US need to be registered with and supervised by the Securities Exchange Commission if their assets under management exceed $\mathbf{2 5 m i l l i o n}$, while smaller investment advisers are required to be registered with state authorities and comply with state regulation. The principal regulative instrument, the Investment Advisers Act 1940 imposes certain prohibitive provisions on the conduct of investment advisers, including fraud, deceit, misrepresentation and acting as principal against clients/dealing against clients. ${ }^{89}$ These specific duties have however been interpreted by case law to represent a more general duty of a fiduciary nature between investment

\footnotetext{
84 [2000] EWCA Civ 234.

85 Joanna Gray, 'Extent of Duty of Care Owed in Pensions Mis-selling' (2001) 9 Journal of Financial Regulation and Compliance 181.

${ }^{86}$ Seymour v Ockwell, above.

${ }^{87}$ FCA Handbook COBS 10A for 'MiFID' business and COBS 10 for non-MiFID business. The criteria for appropriateness as discussed above is not hugely dissimilar from suitability, and focuses on the client's knowledge and understanding of the transaction. Professional customers are not protected under this standard.

${ }^{88}$ FCA Handbook COBS $11.2 \mathrm{~A}$, applying to trading in financial instruments.

${ }^{89}$ S206.
} 
advisers and their customers, ${ }^{90}$ and it is now well-accepted that investment advisers owe their customers a 'federal fiduciary duty'. ${ }^{91}$ As interpreted by case law, the 'federal fiduciary duty' contains aspects such as demanding investment advisers not to put self-interest ahead of customers', ${ }^{\prime 2}$ due disclosure of conflicts of interest, ${ }^{93}$ to treat customers in a fair manner and not to apply discriminatory or preferential practices, ${ }^{94}$ to act with reasonable prudence, diligence and care (i.e. not to be negligent), ${ }^{95}$ and to act in customers' best interests, which may refer to recommending 'suitable' financial products, ${ }^{96}$ or carrying out any trading for customers according to a standard of 'best execution' ${ }^{97}$ The precise contents of the fiduciary duty continues to be subject to interpretation and is recognised as 'fuzzy' by a leading commentator. ${ }^{98}$

The understanding of the 'fiduciary duty' for investment advisers encompasses a proscriptive as well as a positive (care) element, which is not the same position taken in English general law. The fiduciary duty in English law is understood to be a duty of loyalty that is proscriptive in nature and prevents the duty-holder from compromising and damaging the principal's interests. ${ }^{99}$ The negligence standard is regarded as operating separately in relation to conduct. ${ }^{100}$ The application of fiduciary law to financial services contexts is generally limited ${ }^{101}$ and often excluded where customers are regarded as sufficiently sophisticated. ${ }^{102}$ As clarified by the Law Commission, the operation of general fiduciary law in financial services, if applicable, is accepted to be 'modified' by specific regulatory duties that operate akin to contractual modifications to the application of the general duty. ${ }^{103}$ As financial services firms are subject to more precise duties to manage conflicts of interests, and make adequate disclosure to their clients, ${ }^{104}$ protect their clients' assets and moneys

90 SEC v. Capital Gains Research Bureau 375 US 180, 181, at 201 (1963); Santa Fe Industries, Inc. v. Green 430 US 462 (1977); Transamerica Mortg. Advisors, Inc. v. Lewis, 444 U.S. 11 (1979); more recently SEC v Moran \& Ors 922 F. Supp. 867 (1996) at 895-6.

${ }^{91}$ Critically discussed in Arthur C Laby, 'SEC v. Capital Gains Research Bureau and the Investment Advisers Act of 1940’ (2011) 91 Boston University Law Review 1051.

92 SEC v Moran \& Ors, above.

${ }^{93}$ Monetta Financial Services Inc v SEC $390 \mathrm{~F} 2 \mathrm{~d} 952$ ( $7^{\text {th }}$ Circuit, 2004).

${ }^{94}$ SEC v. Tambone, 550 F.3d 106 (1st Cir. 2008).

${ }^{95}$ See Tamar Frankel, Fiduciary Law (Oxford and New York: OUP 2011), at 169-177; Arthur B Laby, 'Fiduciary Obligations of Broker-Dealers and Investment Advisors' (2010) 55 Villanova Law Review 701.

${ }^{96}$ Suitability of Investment Advice Provided by Investment Advisers; Custodial Account Statements for Certain Advisory Clients, Advisers Act Release No. 1406, 59 Fed. Reg. 13,464, (16 Mar 1994).

${ }^{97}$ Advisers Act Release No. 2038, 2002 WL 1343823, at 2 ( 20 June 2002) ("An investment adviser's fiduciary duty includes the requirement to seek best execution of client securities transactions.").

98 Frankel, Fiduciary Law, above at 105.

${ }^{99}$ See Mothew (T/A Stapley \& Co) v Bristol and West Building Society [1996] EWCA Civ 533. Graham Virgo, Principles of Equity and Trust (Oxford; OUP 2016, $2^{\text {nd }}$ ed) at chapter 15.1; Matthew Conaglen, The Nature and Function of Fiduciary Loyalty 121 LQR 452 (2005) discusses the fiduciary duty in English Law as comprising a no-conflict and no-profit rule.

100 Seymour v Ockwell, above.

${ }^{101}$ Woods v Martins Bank Ltd [1959] 1 QB 55; Gerard McMeel and John Virgo, Financial Advice and Financial Products (Oxford; OUP 2014) at ch8.

${ }^{102}$ See strict positions discussed in relation to Singapore and Australia, Adrian Fong, 'Fiduciary Duty in the Context of Providing Investment Services' (2013) JIBLR 390; Joshua Getzler, 'Excluding Fiduciary Duties: The Problems of Investment Banks' (2008) 124 LQR 15.

103 Jack Beatson, The Relationship between Regulations Governing the Financial Services Industry and Fiduciary Duties under General Law in Ewan McKendrick (ed), Commercial Aspects in Trusts and Fiduciary Obligations (Oxford: Clarendon 1992) at ch3. The position that regulatory law prevails over general legal duties is ultimately framed in Law Commission, Fiduciary Duties and Regulatory Rules (Law Com CP No 124, 1995). ${ }^{104}$ Art 23, MiFID 2014; FCA Handbook SYSC 10.1, 10.2. 
in specific ways, ${ }^{105}$ and manage and account for inducements made or received in the course of client business, ${ }^{106}$ these precise regulatory duties have tended to 'thin out' the application of any general fiduciary duty to financial services providers. ${ }^{107}$ In today's context, it would not be particularly meaningful to articulate expectations of financial services providers' conduct of business in general 'fiduciary' terms.

Would any aspect of the 'bundled' fiduciary duty concept in the US be of use to reform considerations in the UK? The 'fiduciary' label used in the US is not appropriate for adoption here, as we have earlier argued that this would cause confusion and disjunction with our tradition of legal interpretation. However, the aspect of 'duty of best interests' could be distinctly appraised and we should consider if the standard of conduct articulated in 'best interests' meets the substantive level called for in relation to the FCA's reform considerations.

The SEC has, as discussed above, included a suitability standard in making recommendations (and continuous monitoring of customers' investments) and a best execution standard in trading, ${ }^{108}$ as part of investment advisers' 'duty of best interests'. As the suitability and best execution standards do not differ materially from the ones imposed here, it may be queried whether the general framing of 'best interests' adds anything more. However, case law interpretation of the duty of best interests could import of a more general expectation. In SEC v Moran ${ }^{109}$ the 'duty of best interests' which is an aspect of the accepted 'federal fiduciary duty' was held to be breached, as the investment adviser had allocated less costly trades to his family members and more expensive trades to his client, costing the client an extra $\$ 7,000$. There is both a proscriptive aspect of not treating the client in an unfavourable manner amongst others as well as having in mind to put the client in the best position possible. On the one hand it can be argued that the 'duty of best interests' is too entangled in the proscriptive aspects to be of any useful meaning to our reform considerations, but on the other hand, there seems to be an expectation of putting the client in the 'best position' possible. The interpretation of this duty does not seem exhausted in relation to precise conduct expectations, and as Frankel puts it,

[F]uzzy rules... could act as a deterrent to violating the law. After all, more people might then avoid coming close to the absolute bright line if they do not know where it precisely is. ${ }^{110}$

\footnotetext{
${ }^{105}$ Art 16(8-10), MiFID 2014, Arts 2-6, Commission Delegated Directive (EU) 2017/593 of 7 April 2016 supplementing Directive 2014/65/EU of the European Parliament and of the Council with regard to safeguarding of financial instruments and funds belonging to clients, product governance obligations and the rules applicable to the provision or reception of fees, commissions or any monetary or non-monetary benefits; FCA Handbook CASS 7.

${ }^{106}$ Art 24(8), 27(2), MiFID 2014; Art 11, Commission Delegated Directive 2017/593 above; FCA Handbook COBS 2.3A.3.5, 6, 8 .

107 Iris H-Y Chiu, 'Is there Scope for Reforming the Emaciated Concept of Fiduciary Law in Finance? Critically Discussing the Potential Achievements of Reform' in Special Issue: Liber Amicorum- Mads Andenas (2017) 27

European Business Law Review 937; Andrew F Tuch, 'The Weakening of Fiduciary Law' in D Gordon Smith and Andrew S Gold (eds), Research Handbook on Fiduciary Law (Cheltenham: Edward Elgar 2018).

108 See $\mathrm{n} 96$ and 97.

109922 F. Supp. 867 (1996).

${ }^{110}$ Fiduciary Law, above at 105.
} 
However, the SEC's recent proposal ${ }^{111}$ to impose a duty of best interests on broker-dealers, ${ }^{112}$ arguably clarifies the duty to the extent that it is may no longer be useful for the FCA's considerations. This is because the clarification defines the contents of the duty to be about the same as is offered under suitability and best execution. The SEC's proposal is derived from a mandate in the Dodd-Frank Act $2010^{113}$ which requires the SEC to consider if the discrepancy in standards imposed on broker-dealers and investment advisers ought to be addressed as brokerdealers' business models now comprise many elements akin to investment advisers' ${ }^{114}$ In articulating the new duty of best interests, the SEC sets it apart from the more stringent 'fiduciary duty' applicable to investment advisers, which calls for higher standards of loyalty. The duty of best interests elevates expectations of broker-dealers' conduct so that they would put customers' financial interests ahead of their own in recommending financial products or conducting financial planning (adhering to a standard of suitability) or carrying out trading (adhering to a best execution standard). In discharging this duty broker-dealers are expected to manage conflicts of interests reasonably and prudently and make adequate disclosure. ${ }^{115}$ This articulation of a 'duty of best interests' as applicable to broker-dealers comprises of the same elements of specific regulatory duties imposed under our regime. In the context of investment advice, there is scope for arguing that the 'duty of best interests' entails higher expectations in relation to 'best position'116 although what precisely are the contours remains indeterminate. In sum, both the Australian and US positions on the nature and extent of investment advisory duties seem to offer something more than our regulatory regime, although that appears not to be the case with non-advisory contexts.

In the next Section, we proceed to discuss the need to systematically determine the shortfalls of the current regulatory regime, in order to clarify the policy choices that the FCA must make. We argue that the FCA needs to make policy choices in four areas: determining the scope of customer protection, the substantive standards of conduct expected, the FCA's enforcement policy and visibility as well as access to customer redress.

\section{B. The FCA's Policy Choices}

The FCA identified the needs underlying its reform considerations, namely: enhancing good conduct on the part of financial services providers, preventing harmful conduct, incentivising good outcomes for financial consumers and improving access to redress. ${ }^{117}$ In particular, the desire to improve conduct is seen as facilitating greater likelihood that financial outcomes for consumers would be favourable. Given that financial products are credence goods, it is challenging for regulation to aim

\footnotetext{
${ }^{111}$ Regulation Best Interests, see Hester Pierce, 'What's in a Name? Regulation Best Interest v. Fiduciary', Speech (24 June 2018) at https://www.sec.gov/news/speech/speech-peirce-072418.

112 when making a recommendation of any securities transaction or investment strategy involving securities to a retail customer.

${ }^{113}$ Section 913 of Title IX of the Dodd-Frank Wall Street Reform and Consumer Protection Act 2010.

${ }^{114}$ See supporting discussions in James J. Angel and Douglas McCabe, 'Ethical Standards for Stockbrokers: Fiduciary or Suitability?' (2013) 115 Journal of Business Ethics 183; Polina Demina, 'Broker-Dealers and Investment Advisers: A Behavioral-Economics Analysis of Competing Suggestions for Reform’ (2014) 113 Michigan Law Review 429; James S Wrona, 'The Best of Both Worlds: A Fact-Based Analysis of the Legal Obligations of Investment Advisers and Broker-Dealers and a Framework for Enhanced Investor Protection' (2012) 68 Business Lawyer 1.

115 Pierce, 2018, above.

${ }^{116}$ See optimistic discussion on the potential for such a broad duty to bring about high and trustworthy standards in investment marketplaces, Edward J Waitzer and Douglas Sarro, 'Fiduciary Society Unleashed: The Road Ahead for the Financial Sector' (2014) 69 Business Lawyer 1081.

${ }^{117}$ FCA, Discussion Paper on a Duty of Care and Potential Alternative Approaches (July 2018).
} 
towards securing good financial outcomes, short of highly interventionist measures in transactional contexts such as imposing guarantees or redistributing financial risks. We argue that four sets of policy choices are relevant to the FCA in pursuing its aims.

First, although the FCA is concerned with sub-optimal financial outcomes for consumers, particularly vulnerable consumers, ${ }^{118}$ the small business series of litigation should also raise the question as to what scope of financial services customers the FCA should be concerned about in relation to achieving sub-optimal outcomes. Is there a need to consider if financial services customers are aggressively classified as non-retail? We argue that the FCA should take the opportunity to consider the theoretical and policy justifications for the scope of protection offered to its three-fold categories of financial customers- 'retail' and 'professional' customers, and 'eligible counterparties' to consider if the existing scope of protection in its 'retail' and 'professional' categories need rethinking.

Second, in relation to enhancing conduct on the part of financial services firms, there is regulatory interest in preventing harm i.e. instilling ex ante paradigms for behaviour, as well as connecting conduct with facilitating 'good outcomes' for consumers. We suggest that a case can be made for a hybrid design of general and specific regulatory duties based on theoretical perspectives in regulation. However, we caution that radical thinking may be required if regulation were to be designed to secure good financial outcomes for consumers.

Third, although FCA enforcement is ex post in nature, regulatory penalties are well-perceived as having a deterrent effect. ${ }^{119}$ There are however flaws in the FCA's enforcement policy and responsiveness, and in particular there may be a need to deal with perceptions of discrepancy in relation to enforcement against large versus smaller firms.

Fourth, the FCA acknowledges that there is a perception that redress against financial services providers may be limited and unsatisfactory. We are of the view that there is a stronger role the FCA can play in fostering consumer redress as part of public regulatory law instead of leaving to a bilateral or transactionalised narrative in consumer redress. We argue that the FCA's retreat from fostering consumer redress as a public regulatory role is mistaken. However we also look the range of options in securing consumer redress and argue that access to private justice must be made more robust.

\section{The Scope of Protection for Financial Customers}

The scope of protection for financial customers is delineated according to type of customer, ie retail, professional or eligible counterparty discussed in Section A, as well as according to the type of transaction in question, such as the advisory versus non-advisory contexts. Retail customers enjoy the highest level of protection in both advisory and non-advisory contexts, but advisory contexts also entail more obligations for financial services providers compared to non-advisory transactions. There is also a greater propensity to regard a transaction as objectively 'advisory' if retail customers are involved even in an execution-only context as long as the customer's attention is not drawn sufficiently to the latter. ${ }^{120}$

\footnotetext{
${ }^{118}$ Ch8, FCA, FCA Mission - Our Future Approach to Consumers (2017) at https://www.fca.org.uk/publication/corporate/our-future-approach-consumers.pdf.

${ }^{119}$ See 'Enforcement and Credible Deterrence', speech by former FCA Director Tracey McDermott, 18 June 2013 at https://www.fca.org.uk/publication/news/enforcement-credible-deterrence-speech.pdf.

${ }^{120}$ Rubinstein v HSBC [2011] EWHC 2304 (QB) , [2012] EWCA Civ 1184.
} 
resource-limited. However, both transaction and customer types are proxy factors only for calibrating regulatory risk, and such proxy factors can at times be too crude or inadequate.

\section{A Case for Consistent and High Levels of Protection for Retail Customers in Advisory and Non- advisory Contexts?}

Retail customers are not protected in non-advisory 'execution-only' contexts except in relation to communications duties. Execution-only products are supposed to be highly liquid, non-complex and supported by sufficient publicly available information, hence customers are regarded as not being in need of protection when accessing them. ${ }^{123}$ Further, the FCA's communications duties of being 'fair, clear and not misleading' which have been augmented under European regulation now govern communications to be balanced in terms of benefits and risks, and transparent in relation to potentially disadvantaging matters such as divestment difficulties, price volatility and fees and charges. ${ }^{124}$ On a risk-based approach to regulation it may be argued that execution-only contexts are sufficiently empowering and warrants less regulatory protection. However, this assumes that individuals are able to access and process available information and engage in rational decisionmaking. As Moloney points out, the model of the informationally-rational investor is largely hypothetical, and real retail investors are generally 'trusting' of their service providers and the regulatory framework. ${ }^{125}$ We query whether the 'lowest common denominator' in the retail customer landscape, or the vulnerable customer can be adequately supported by publicly available information and the context of normally high liquidity, given their lack of financial literacy ${ }^{126}$ and behavioural heuristics? ${ }^{127}$

It may be argued that the execution-only paradigm meets the needs of access to finance at a reasonably cost-effective level. However, we note a different approach under the Insurance Distribution Directive where the standard of appropriateness may be attracted even in a nonadvisory context, and execution-only contexts may be permitted by Member States as a matter of discretion. ${ }^{128}$ Less assumption seems to be made with regard to customers' ability to dispense of their reliance on intermediaries, and perhaps this approach should be considered more carefully for execution-only products across the financial services sector.

\footnotetext{
${ }^{123}$ Art 25, MiFID 2014.

${ }^{124}$ Art 48, Commission Delegated Regulation 2017/565/EU, FCA Handbook COBS 4.2.

${ }^{125}$ N Moloney, "Effective Policy Design for the Retail Investment Services Market: Challenges and Choices post FSAP" in G Ferranini and E Wymeersch (eds), Investor Protection in Europe (Oxford: OUP 2006) at pp381-416, How to Protect Investors (Cambridge: CUP 2010).

${ }^{126}$ Sue Lewis and Dominic Lindley, 'Financial Inclusion, Financial Education, and Financial Regulation in the United Kingdom' (ADBI Working Paper 2015) at https://papers.ssrn.com/sol3/papers.cfm?abstract id=2672777.

${ }^{127}$ Folarin Akinbami, 'Financial Services and Consumer Protection After The Crisis' (2011) 29 International Journal of Bank Marketing 134-147; John Y Campbell, 'Restoring Rational Choice: The Challenge of Consumer Financial Regulation' (ECB Working Paper 2016) at https://papers.ssrn.com/sol3/papers.cfm?abstract $i d=2770585$ discussing various heuristics that may impede optimal or rational financial decision-making. Behavioural heuristics can affect more vulnerable customers in a more adverse manner, Michael S. Barr, Sendhil Mullainathan and Eldar Shafir, 'Behaviourally Informed Regulation' in Michael S Barr, The Financial Lives of Low-Income Americans (Brookings Institution Press 2012); FCA, Applying Behavioural Economics at the Financial Conduct Authority (Occasional Paper 2013). ${ }^{128}$ Art 30(3), Directive (EU) 2016/97 of the European Parliament and of the Council of 20 January 2016 on insurance distribution (recast), the inconsistencies between levels of financial customer protection are lamented in Veerle Colaert, 'MiFID II In Relation To Other Investor Protection Regulation: Picking Up The Crumbs Of A Piecemeal Approach' (2016) at https://papers.ssrn.com/sol3/papers.cfm?abstract_id=2942688.
} 
In the age of financialisation ${ }^{129}$ where the private financial sector has become the first port of call for managing staple financial needs, retail consumers are a massive market for various products in banking, saving, investment and insurance. With the rise of bancassurance and now universal banking business models globally, ${ }^{130}$ the penetration of financial supermarkets into social life cannot be overstated. ${ }^{131}$ The level of financial customer protection and the assumptions underlying current policy are arguably terms of the 'social contract'132 that ought to be subject to wider social discourse. For example, we need a fresh policy discourse and determination into whether the financialisation footprint has entailed a level of financial consumer maturity so that certain basic or staple products may comfortably fall within non-advisory contexts, or whether financialisation has resulted in funnelling masses to financial markets but consumers remain none the wiser and disempowered in ordering their financial lives. ${ }^{133}$ Commentators consistently reveal the low levels of financial literacy in populations in developed financial jurisdictions ${ }^{134}$ which ought to raise concern regarding the assumptions of financial consumers' capabilities.

Further, sub-optimal industry practices that exploit less savvy, ${ }^{135}$ 'stupidly loyal' ${ }^{136}$ or vulnerable customers ${ }^{137}$ have been extensively revealed, not only in the UK but in many relatively mature and financialised jurisdictions. Commentators have written extensively about how financially marginal customers may become trapped in paying high charges and fees for banking products while subsidising the sophisticated and financially healthy. ${ }^{138}$ Vulnerable customers may become trapped

\footnotetext{
${ }^{129}$ defined as 'the increasing role of financial motives, financial markets, financial actors and financial institutions in the operation of the domestic and international economies' Gerald A Epstein, 'Introduction: Financialization and the World Economy' in Gerald A Epstein ed, Financialization and the World Economy (Cheltenham: Edward Elgar, 2005) at 3.

${ }^{130}$ S McGee, Chasing Goldman Sachs: How the Masters of the Universe Melted Wall Street Down and Why They'll Take us to the Brink Again (New York: Crown Business 2010); AE Wilmarth Jnr, 'The Dark Side of Universal Banking: Financial Conglomerates and the Origins of the Subprime Financial Crisis' (2009) 41 Connecticut Law Review 963 on the rise of global universal banking; Gordon L Clark and Darius Wójcik, The Geography of Finance (Oxford: OUP, 2007) at ch8.

${ }^{131}$ Ismail Erturk, Julie Froud, Sukhdev Johal, Adam Leaver and Karel Williams, 'The Democratization of Finance? Promises, Outcomes and Conditions' (2007) 14 Review of International Political Economy 553.

${ }^{132}$ Also discussed in relation to banking regulation and the role of banks, Mehrsa Baradaran, 'Banking and the Social Contract' (2014) 89 Notre Dame L. Rev. 1283.

${ }^{133}$ Ismail Erturk, Julie Froud, Sukhdev Johal, Adam Leaver and Karel Williams, 'Financialisation, Coupon Pool and Conjuncture' in Ismail Erturk, Julie Froud, Sukhdev Johal, Adam Leaver and Karel Williams (eds), Financialization At Work: Key Tests and Commentary (Oxford: Routledge, 2008); Paul H Dembinski, Finance: Servant or Deceiver (transl by Kevin Cook, Basingstoke: Palgrave Macmillan 2009); Paul Langley, 'Uncertain Subjects of Anglo-American Financialization' (2007) 65 Cultural Critique 67.

${ }^{134}$ Lewis and Lindley, 2015, above; Annamaria Lusardi and Olivia S Mitchell, 'Financial Literacy Around the World' (2011) 10 J Pension Econ Financ 497-508.

135 Those that may not compare the market sufficiently, or unaware of channels for financial empowerment, see different levels of ignorance discussed in Campbell, 'Restoring Rational Choice (2016), above.

${ }^{136}$ Such as customers who lose out by not switching away from their financial services provider, investigated in Citizens Advice, 'The Insurance Loyalty Penalty' (2018) at https://www.citizensadvice.org.uk/Global/CitizensAdvice/Consumer\%20publications/Report\%20\%20Insurance\%20loyalty\%20penalty.pdf.

137 John Y. Campbell, Howell E. Jackson, Brigitte C. Madrian and Peter Tufano, 'Consumer Financial Protection' (2011) 25 Journal of Economic Perspectives 91 on whether the least privileged or advantaged require more protection.

${ }^{138}$ Above; Nicholas Ryder \& Rachel Thomas, 'Convenient Credit and Consumer Protection - A Critical Review of the Responses of Labour and Coalition Governments' (2011) 33 Journal of Social Welfare \& Family Law 85-95.
} 
in unaffordable high cost credit products ${ }^{139}$ that may help them fight fires in the short term ${ }^{140}$ but entail longer-term devastating consequences. ${ }^{141}$ 'Stupidly loyal' customers may lose out financially by not attempting to switch financial services providers, ${ }^{142}$ although research costs could be the lowest for the sophisticated and savvy in a competitive market. Many of these findings relate to relatively non-complex products in the market, and repeated tales of consumer mis-selling ${ }^{143}$ raise for us the question of whether consumers would benefit more from consistent levels of consumer protection across advisory and non-advisory contexts.

\section{A Case for Addressing the Denuding of Regulatory Protection for Borderline Elective Professional Customers?}

Next, we argue that the scope of financial regulatory protection for certain non-retail customers who may be 'borderline' has been aggressively denuded by market practice and there is a case for challenging such market practice. Non-retail customers enjoy less regulatory protection, as discussed in Section A, but borderline customers may be offered 'execution-only' transactions so that financial firms do not even owe them the already thin duty in appropriateness. In the small business series of litigation discussed earlier, customers that purchased interest-rate hedging products ranged from sophisticated ${ }^{144}$ to relatively unsophisticated small outfits ${ }^{145}$ equally classified as non-retail customers in 'execution-only' transactions. These transactions also featured certain aspects of complexity. In this context, the risk-based approach to justifying a lower level of regulatory protection for non-retail customers may be misplaced, as it does not address the potential over-inclusion into the 'low risk' category of persons who may be borderline. Further, as Baldwin and Black warn, ${ }^{146}$ in the wake of the global financial crisis, where assumptions of 'low regulatory risk' are made, the question of whether these risks are large if they materialise, is also often ignored. There is a need for regulators to take greater care with areas of perceived lower risk by considering the extent of damage that may occasion if these risks materialise. Where there is 'high impact', regulators may wish to adopt more nuanced approaches to risk-based regulation.

It may be argued that non-retail customers would unlikely have access to a wide range of products if a retail level of consumer protection is maintained for them. We offer two counterarguments to this:

${ }^{139}$ FCA has looked into high cost credit products, first introducing a cap on payday loan interest charges, see https://www.fca.org.uk/news/press-releases/agenda-priorities-consumer-credit on review and retention of this policy; High Cost Credit Review which concluded in May 2018 to bring about higher standards of customer protection in various products from store and catalogue credit to bank overdrafts, https://www.fca.org.uk/news/press-releases/fca-publishes-outcome-high-cost-credit-review.

${ }^{140}$ Campbell et al, 2011, above.

${ }^{141}$ Lewis and Lindley, 2015, above.

142 N136.

${ }^{143}$ N3 on PPI mis-selling, also card protection mis-selling dealt with by the FSA under a consumer redress scheme between 2015-16, https://www.fca.org.uk/news/press-releases/consumer-redress-scheme-opens\%E2\%80\%93-card-security-product-holders-have-until-march; and cases subject to enforcement such as the mis-selling of Arch Cru funds (2014), https://www.fca.org.uk/news/press-releases/\%C2\%A331mcompensation-be-paid-out-following-fca\%E2\%80\%99s-arch-cru-consumer-redress-scheme, Gracechurch Investments Itd (2011), at https://www.fca.org.uk/news/press-releases/former-chief-executive-stockbrokerfirm-fined-\%C2\%A3450000-and-banned; Beaufort Securities (2018) at https://www.fca.org.uk/news/newsstories/information-customers-beaufort-securities-limited-bsl-and-beaufort-asset-clearing-services-limited. ${ }^{144}$ Titan Steel Wheels Ltd, above.

${ }^{145}$ Eg Crestsign, above.

${ }^{146}$ Robert Baldwin and Julia Black, 'When Risk Based Regulation Aims Low' (2012) Regulation and Governance $1,131$. 
one is that more nuanced levels of protection for the 'borderline' non-retail customer can range from the Insurance Distribution Directive approach of requiring appropriateness, to requiring mandatory independent financial advice, to allowing execution-only classifications of the contract to be challenged. ${ }^{147}$ In other words, there is arguably a range of options that do not necessarily entail defaulting to the retail standard. Two, the argument in favour of 'financial inclusion' cannot be sustained as financial inclusion should not come at a price of 'lemons' in the market and a general lack of willingness to assume a socially acceptable level of responsibility for building financial markets. By 'lemons' in the market, we refer to commercial practices that may converge at a low level and remain unchallenged as prevailing practice if there is a lack of regulatory intervention. Aggressively classifying clients as professional and engaging them in 'execution-only' contracts aligns with the financial incentives of firms to pursue least cost/responsibility and maximum profit from each transaction. These incentives are unlikely to be corrected by market developments. Further, the social landscape has been fundamentally transformed by financialisation, and financial firms ought not to be allowed to constantly rely on disclaimers of responsibility in bilateral narratives, a phenomenon that is increasingly incompatible with the financial sector's social footprint and expectations of responsibility commensurate with its power and footprint. ${ }^{148}$

The appeal of the proposed 'duty of care' may lie in its nature as a 'general duty', such duty expected to fill the regulatory gaps in the scope of protection we have discussed above. However, unless otherwise clarified, the 'duty of care' itself does not magically fill existing gaps in scope of protection, as such a duty may still not apply to 'non-complex execution-only' or other 'executiononly' situations for non-retail customers. The duty may still only be actionable by private persons unless the scope of persons entitled to bring civil proceedings for breach of regulatory duties is expanded. ${ }^{149}$ In other words, specific policy choices would have to be made in relation to particular gaps such as the scope of protection and redress avenues.

\section{The Standards of Protection}

There are two issues that arise from the FCA's consultation in relation to standards of protection. One relates to whether existing standards are 'too low' and the other relates to whether existing standards are able to 'prevent harm' by instilling good ex ante conduct.

As discussed in Section A, the general duty of care would unlikely introduce a standard that exceeds those of existing regulatory duties in order to address their perceived shortfalls. Judicial interpretation has clarified that the general standard of care is likely to be interpreted no differently from the applicable regulatory content. ${ }^{150}$ However, it can be perceived that (a) the general conduct principle established by the FCA in 'treating customers fairly' is too undemanding; and (b) specific regulatory duties offer 'low' protective standards.

\footnotetext{
147 The highly procedural approach in Maple Leaf Macro Volatility Master Fund v Jacques Rouvroy [2009] EWHC 257 (Comm); [2009] 1 Lloyd's Rep 475 at paragraph 353 tends to protect financial institutions rather than engage meaningfully with the normative dimension of client categorisation.

148 Joanna Benjamin, 'The Narratives of Financial Law' (2010) 30 OJLS 787; Julia Black, 'Reconceiving Financial Markets-From the Economic to the Social' (2013) 13 Journal of Corporate Law Studies 401.

149 Under s138D, FSMA.

${ }^{150}$ Seymour v Ockwell, above; David Anderson v Openwork Limited 2015 WL 3795707.
} 
In relation to (a), 'Treating customers fairly' (TCF) can be implemented at firms by overly focussing on procedures and providing lengthy communications to customers in a risk-averse manner. ${ }^{151}$ This is because TCF is often regarded to be meta-regulatory ${ }^{152}$ in nature. However, the enforcement of 'TCF' by the FCA has demonstrated its power beyond such procedural compliance. ${ }^{153}$ The court in British Bankers' Association v FSA also affirmed the position of 'principles' as being the bedrock upon which specific regulatory duties are founded ${ }^{154}$ and that principles can found an enforcement action as such.

In relation to (b), specific regulatory duties can be perceived as not being sufficiently potent as the language that they are cast in is often procedural and prescriptive, and sometimes lacks an allencompassing and normative quality. Specific duties such as regulatory duties to make 'fair, clear and accurate' communications, ${ }^{155}$ to manage inducements such as research payments, ${ }^{156}$ preparing independent and untainted investment research, ${ }^{157}$ or holding customers' monies or assets in specified manners of custodial protection, ${ }^{158}$ set out clear ex ante steps that financial services providers must comply with in order to meet a desired level of protection. These can be perceived to be focused and more easily subject to cleverly-designed avoidance. Further, the procedural focus in these duties can obscure the underlying ethicality that they are designed to facilitate. However, specific duties can be more effective in shaping ex ante behaviour ${ }^{159}$ as firms have little discretion to deviate from certain prescribed steps. Although the sum of many such steps may seem to be procedural in nature, the fulfilment of those steps could approximate well for the attainment of a substantive level of protection for customers.

There may be a perception gap between stakeholders and the regulator in relation to the potency of TCF and specific regulatory duties. However, a valid point is that a generally-framed duty may be more encompassing in nature, and can be framed in a manner that is not coupled with proceduralisation in order to make normative pronouncement on expected standards of behaviour.

\footnotetext{
${ }^{151}$ See Andromachi Georgosuli, 'The FSA's 'Treating Customers Fairly' (TCF) Initiative: What is So Good About It and Why It May Not Work' (2011) 38 Journal of Law and Society 405. Empirical research by Sharon Gilad also points out that it is firm implementation that is sub-optimal as empirical research shows a disjunct between regulatory expectations and firm implementation, a hazard that has been well-discussed in relation to highlevel principles-based regulation at a 'meta-level' that delegates practical implementation to firms, see Sharon Gilad, 'Institutionalizing Fairness in Financial Markets: Mission Impossible?' (2011) 5 Regulation and Governance 309-332, 315.

152 Which means couched in general terms and principally devolved to firms to implement, see Cary Coglianese and Evan Mendelson, 'Meta-Regulation and Self-Regulation' in Robert Baldwin, Martin Cave, and Martin Lodge (eds), The Oxford Handbook of Regulation (Oxford: OUP 2010).

${ }^{153}$ Eg FSA's enforcement against Kensington Mortgage Company Ltd for their sharp treatment of customers in arrears, implementing a payment scheme that would make paying off the principal arrears owed extremely challenging.

154 [2011] EWHC 999.

155 Commission Delegated Regulation 2017/565/EU, above.

156 See n106.

157 Commission Delegated Regulation 2017/565/EU, above at Arts 36, 37.

158 See $\mathrm{n} 105$.

${ }^{159}$ Laetitia B. Mulder, Jennifer Jordan, Floor Rink, 'The Effect of Specific and General Rules on Ethical Decisions' (2015) 126 Organizational Behavior and Human Decision Processes 115. Specific duties also tend to produce a more precise level of care relevant for each activity, see Paul G. Mahoney and Chris William Sanchirico, 'General and Specific Legal Rules' (2005) 161 Journal of Institutional and Theoretical Economics 329, although these precise steps may be lobbied by firms so that regulators would incorporate what is convenient for them.
} 
The mixed achievement of proceduralisation in changing firms' culture has been discussed, ${ }^{160}$ and there is scope for introducing a stronger normative expectation in order to shape firms' behaviour.

We think an approach that draws from both the strengths of general and specific duties can be considered in the FCA's endeavour to raise the standards in regulatory protection. For example, the Australian duty of best interests in the advisory context contains both aspects of ex ante steps in specific duties, as well as a general ex post 'catch-all' that is desired to signal normative levels of expectation. The general formulation is also a position adopted in the Dodd-Frank Act that empowers the Consumer Financial Protection Bureau to prevent 'abusive' practices to financial consumers. ${ }^{161}$ General formulations often run against the industry's resistance as the industry prefers up-front clarity instead of potential traps for liability in the future. ${ }^{162}$ However a lack of clarity could also cause financial services providers to behave in a more circumspect manner, ${ }^{163}$ so that bright-line boundaries would not merely promote boundary-pushing behaviour.

A combination of specific and general duties can work optimally to provide ex ante clarity and even safe harbours, as well as provide an open-ended moderating influence to incentivise good, ethical and professional behaviour. In this way the general duty can function to elevate the expected standards of behaviour beyond mere compliance with 'specific regulatory steps'. We suggest a general duty should optimally be a 'catch-all' add-on to specific duties, and not in the form proposed in the FCA consultation.

The Australian 'best interests' add-on could supplement our existing duties in suitability and appropriateness. Further, another area that can benefit from such an 'add-on' is the regulation of how firms manage their conflicts of interest. Many financial firms implement weakly their duties to manage conflicts of interest, ${ }^{164}$ as a general fiduciary duty is not of great relevance. ${ }^{165}$ The highly ex ante and procedural duty for firms to 'manage and disclose conflicts of interests' can be supplemented by a general formulation to 'take any other reasonable step to ensure that customers' interests are treated in a professional, honest and ethical manner'. The broad framing in the italicised phrase could address some of the concerns with regard to ready exclusions of fiduciary duties in financial sector transactions ${ }^{166}$ and provide some rebalancing in the strictly bilateral and transactional narratives underlying these financial relationships. The formulation of a general 'catchall' add-on should be developed in relation to each area of specific duties, as customers' needs differ in different service contexts. Hence a general across the board 'duty of care' as proposed is arguably too crude a measure to elevate standards of protection. Indeed such a general articulation is likely to suffer the same interpretive fate as Busch has suggested above for the MiFID umbrella 'duty of best interests', which can be regarded as fleshed out by and not adding to specific regulatory duties.

\footnotetext{
${ }^{160}$ Sharon Gilad, 'Institutionalizing Fairness in Financial Markets: Mission Impossible?' (2011) 5 Regulation and Governance 309.

${ }^{161}$ Rebecca Schonberg, 'Introducing "Abusive": A New and Improved Standard for Consumer Protection' (2012) 100 California Law Review 1401.

162 Thilla Rajaretnam and Angus Young, 'In the Best Interest of Clients? A Reappraisal of the Recent Reforms in the Regulation of Financial Advisors in Australia' (2015) ICCLR 39.

${ }^{163}$ Frankel, above.

${ }^{164}$ Christoph Kumpan and Patrick C Leyens, Conflicts of Interest of Financial Intermediarie' 5 European Company and Financial Law Review 72 (2008).

165 Chiu, The Emaciated Concept, above.

${ }^{166}$ See Adrian Fong, 'Fiduciary Duty in the Context of Providing Investment Services' (2013) JIBLR 390; Joshua Getzler, 'Excluding Fiduciary Duties: The Problems of Investment Banks' (2008) 124 LQR 15.
} 
One question would be how general 'catch-all' add-ons to specific duties sit alongside the overall 'TCF' principle? TCF arguably remains useful for service contexts where reforms of both general and specific duties have not taken place. In other words, the service context of advice may be highly developed with specific duties plus our proposal to add a general 'catch-all' add-on, but as financial services change and develop, there may be new and innovative contexts that regulation needs to address. In these areas, an overall TCF principle is still useful for setting out a baseline expectation of behaviour.

Finally, one issue that the FCA is concerned about is how financial outcomes may be improved by the imposition of a duty of care. In essence, do legal duties correlate with improved outcomes? Unlike in product liability duties, financial regulation duties may not affect the outcomes of credence goods. All financial products feature a risk/return trade-off, and financial markets are far from predictable, being highly susceptible to boom and bust. ${ }^{167}$ Regulatory duties, whether specific or generally-framed, have in common their focus on pre-sale contexts. Any post-sale adjustments would likely be distributive in nature, and there is a genuine lack of thinking in this respect. ${ }^{168}$ In Micklitz and Domurath's volume, a number of commentators ${ }^{169}$ argue that the advent of profinancialisation government policies warrant consideration of whether there is a public interest in introducing regulation that may have ex post adjustment and distributive effects. Ex ante pre-sale regulatory duties cannot extend to rewriting contracts, ${ }^{170}$ or addressing poor financial outcomes.

Pro-financialisation policies effect a welfare-credit trade-off, as markets and not the state become the location for meeting a variety of financial needs. The marketization and privatisation of consumer financial needs exposes consumers to the vicissitudes of markets which may fail their expectations, or fail to take into account of unexpected events in the consumers' financial lives. There is a need to consider if regulation should intervene in ex post contractual adjustment to relieve the harshness of outcomes for consumers, ${ }^{171}$ to provide debt relief, ${ }^{172}$ and other forms of risk distribution. ${ }^{173}$ These measures may be particularly pertinent to vulnerable or unequal consumers. ${ }^{174}$ Further, Shiller also proposes that financialisation should be accompanied by democratisation duties ie duties to assist customers in optimally managing their financial risk. ${ }^{175}$ There is however a risk of over-financialising the customer in this way ${ }^{176}$ and there would remain the need to consider ex post supporting policies.

\footnotetext{
${ }^{167}$ Hyman Minsky, 'The Financial Instability Hypothesis' (1992) at http://www.levyinstitute.org/pubs/wp74.pdf 168 The spectrum of consumer law is discussed in Chris Willett, 'Retheorising Consumer Law' (2018) 77 CLJ 279.

${ }^{169}$ Guido Comparato, 'The Design of Consumer and Mortgage Credit Law in the European System' in Hans W Micklitz and Irina Domurath, Consumer Debt and Social Exclusion in Europe (Surrey: Ashgate, 2015) at ch2; Elaine Kempson, 'Overindebtedness and its Causes across European Countries' in the same volume at ch9. 170 James Heintz and Radhika Balakrishnan, 'Debt, Power, and Crisis: Social Stratification and the Inequitable Governance of Financial Markets' (2012) 64 American Quarterly 387 on the externalities of financial inclusion. ${ }^{171}$ Such as using the doctrine of frustration, see Kempson, n168 above.

172 Hans W Micklitz, 'Conclusions: Consumer Over-indebtedness and Consumer Insolvency: From Micro to Macro' in Hans W Micklitz and Irina Domurath, Consumer Debt and Social Exclusion in Europe above at ch13 ${ }^{173}$ Such as charge caps, FCA's reforms as discussed earlier, and in the US see Sumit Agarwal, Souphala Chomsisengphet, Neale Mahoney and Johannes Stroebel, 'Regulating Consumer Financial Products: Evidence from Credit Cards' (NBER Working Papers 2013) at http://www.nber.org/papers/w19484.

174 N118.

175 Robert J Shiller, 'Democratizing and Humanizing Finance' in Benjamin M Friedman (ed), Reforming U.S. Financial Markets (Mass: MIT Press 2011).

${ }^{176}$ Such as the interest-rate hedging products that British small businesses were sold, discussed in Section A.
} 


\section{Enforcement}

Whether customer protection is achieved can be perceived in the context of how discovered harms are dealt with. Stakeholder perception of regulatory flaws leading up to the FCA consultation may be in part due to the regulator's flaws in relation to supervision and enforcement, and not necessarily extensive flaws in the regulatory standards. We have distinguished the issues in scope and standards of regulatory protection above, but enforcement deficits or inconsistency are separate problems altogether. Visible and successful ex post enforcement often proxies for successful administration of regulation by the regulatory agency. This is because preventive benefits are neither visible nor readily quantified. ${ }^{177}$ The FCA is separately consulting on its enforcement approach in order to improve transparency and fairness in dealing with regulated firms, as well as to achieve robust and credible enforcement. ${ }^{178}$ We highlight the FCA's enforcement problems below.

First, the public expects enforcement to be timely, as enforcement that is protracted tends to give the impression of inefficiency and even injustice. ${ }^{179}$ The FCA's consultation paper ${ }^{180}$ sets out its processes of harm identification, investigations and the need to be satisfied of sufficient evidence and public interest before bringing any case. Although time taken is necessary for the gathering of salient evidence and securing greater chances of successful enforcement, the Green report has criticised the FSA ${ }^{181}$ for taking three years to complete investigation and enforcement against a single individual, Peter Cummings, of the Halifax Bank of Scotland which nearly failed in the global financial crisis. Further, a case made against a regulated entity can at first instance be challenged by the entity before the internal Regulatory Decisions Committee prior to formal enforcement. There are concerns that this stage allows firms to water down their cases. ${ }^{182}$

Second, a regulatory agency could be more efficient in securing enforcement as it does not suffer from collective action problems or the costs of access to justice by individuals, since its enforcement function should enjoy economies of scale. ${ }^{183}$ However, enforcement efficiency can be affected if the regulatory agency makes poor or weak judgments such as regarding chances of success. For example, the Green report ${ }^{184}$ found the FSA's lack of investigations into other responsible persons in HBOS, given evidence of failure and mismanagement emerging from different parts of the bank, to be 'unreasonable' on the whole. The FCA's consultation paper on enforcement sets out a matrix of factors such as evidential strength and public interest that may affect its enforcement decision, and what may cause concern is the FCA's view that ' $f$ ] irms and individuals should not wait for an investigation to end before acting in a way they think is right. We encourage firms and individuals to

\footnotetext{
177 Howell Jackson, "Variation in the Intensity of Financial Regulation: Preliminary Evidence and Potential Implications" (2007) 24 Yale Journal on Regulation 253.

${ }^{178}$ FCA, Our Approach to Enforcement (21 March 2018).

179 The adage that justice delayed is justice denied, and see critique of ASIC's slow enforcement, Glen Lewis, 'Australia's Regulatory Panopticon' (2013) 84 Australian Quarterly 26;

${ }^{180}$ Above, n178.

${ }^{181}$ Andrew Green QC, Report into the FSA's Enforcement Actions Following the Failure of HBOS (2015) at https://www.bankofengland.co.uk/-/media/boe/files/report/2015/andrew-green-report-into-fcaenforcement-actions-following-failure-of-hbos.pdf.

182 'FCA overhaul risks deluge of contested enforcement probes', The Telegraph (1 Feb 2017).

183 The effect of credible enforcement creating a regulatory brand and instilling market confidence is discussed in John C Coffee, "Law and the Markets- The Impact of Enforcement" (2007) 156 University of Pennsylvania Law Review 229.

${ }^{184}$ Green report above, although a preliminary report that the FSA commissioned suggested for example that a case would be challenging against the former HBOS CEO, Andy Hornby.
} 
examine their own affairs and, where appropriate, take their own remedial action. ${ }^{185}$ Decoupling enforcement from private actions is arguably contrary to increased public expectations of the 'representative' capacity of the powerful financial services regulator in addressing wrongs and harms. These are increasingly perceived as 'social' and not just transactional harms. ${ }^{186}$ Further, we argue below that it is the coupling and not decoupling of enforcement and redress that will likely induce more public confidence in the FCA.

Third, the FCA may also suffer from the perception of lack of consistency in enforcement, which can be damaging to enforcement credibility. In its first enforcement decision under the new Senior Managers Regime, the regulators decided to warn and fine Jes Staley, CEO of Barclays plc after revelations that he had tried to uncover the identity of a whistleblower who raised concerns about an appointment he made in the bank. The conduct raised issues of integrity and abuse of power and could be regarded as serious under the new regime of conduct rules for senior managers. ${ }^{187}$ The enforcement has been criticised as 'soft', 188 and also raises the question whether discrepant treatment between larger and smaller firms exist. In the Barclays case, the systemically important profile of the bank may have militated against enforcement action that is too disruptive, such as the disqualification of its CEO. One of us earlier discussed the greater ease with which individuals in larger firms are able to be shielded from liability through diffuse organisational responsibility, as compared to enforcement actions taken against individuals in smaller firms. ${ }^{189}$ Nevertheless it has to be borne in mind that record monetary fines have been levied against large firms too for money laundering and benchmark manipulation. ${ }^{190}$

Finally, financial customers may not perceive that effective enforcement has been carried out until a wrong-doing firm or individual has been punished and ordered to compensate for the harms caused. ${ }^{191}$ There is a lack of consistent coupling between enforcement and redress, as a redress order does not always accompany FCA enforcement. ${ }^{192}$ Experience with the US Consumer Financial Protection Bureau for example shows a different approach. ${ }^{193}$ We now turn to redress avenues which we argue are in need of significant improvement.

\footnotetext{
${ }^{185}$ Above n178 at p10.

${ }^{186}$ Edward L Glaeser and Andrei Shleifer, 'The Rise of the Regulatory State' (2003) 41 Journal of Economic Literature 401-425; but enforcement need not mean punishment and the gradations of responsive regulation, Ayres and Braithwaite, cit above, are efficient under different contexts, see P. Fenn and C. G. Veljanovski, 'A Positive Economic Theory of Regulatory Enforcement' (1988) 98 The Economic Journal 1055.

${ }^{187}$ FCA Handbook COCON, as well as s59ZA, 66A and 66B, FSMA 2000.

188 'UK regulators criticised for fine against Barclay's chief', Financial Times (20 April 2018).

${ }^{189} \mathrm{Ch} 7$, Iris H-Y Chiu, Regulating from the Inside: The Legal Framework for Internal Control at Banks and Financial Institutions (Oxford: Hart 2015); also see discussion re the SEC in the US, Stavros Gadinis, 'The SEC and the Financial Industry: Evidence from Enforcement Against Broker-Dealers' (2012) 67 Business Lawyer 679. ${ }^{190}$ Eg see 'Libor rigging fines- a timeline', The Guardian (23 Apr 2015) on a summary of banks hit with fines for manipulating the LIBOR benchmark; 'FCA fines Deutsche Bank $f 163$ million for serious anti-money laundering controls failings' (31 Jan 2017) at https://www.fca.org.uk/news/press-releases/fca-fines-deutsche-bank-163million-anti-money-laundering-controls-failure.

${ }^{191}$ A point we will return to in the final section.

${ }^{192}$ A number of enforcement actions included redress schemes, such as Final Notice for Alliance and Leciester (2008) but this approach is discretionary.

193 Leonard J Kennedy, Patricia A McCoy and Ethan Bernstein, 'The Consumer Financial Protection Bureau: Financial Regulation for the twenty-First Century' (2012) 97 Cornell Law Review 1141; Eric J. Mogilnicki and Melissa S. Malpass, 'The First Year of the Consumer Financial Protection Bureau: An Overview' (2013) 68 Business Lawyer 557 where enforcement actions coupled with compensation orders for customers was discussed.
} 


\section{Customer/consumer Redress}

It is easy to perceive legal or regulatory duties as impotent because customer/consumer redress is fraught with trouble or not attained. The FCA's consultation paper only referred to redress issues narrowly by asking if a new duty should be supported by a right of private action. In view of the FCA's reforms to access to the Ombudsman's service, ${ }^{194}$ the FCA should be prepared to take a broader view in reforming consumer/customer redress across the 'public to private' paradigms as we argue below.

restitution order

\begin{tabular}{l}
\hline $\begin{array}{l}\text { Ombudsman } \\
\text { service }\end{array}$ \\
\hline
\end{tabular}

'delegated' redress schemes such as s404 or other special schemes

\begin{tabular}{|l|}
\hline Complaints \\
processes at \\
firms
\end{tabular}

Private litigation s138D
Private

litigation
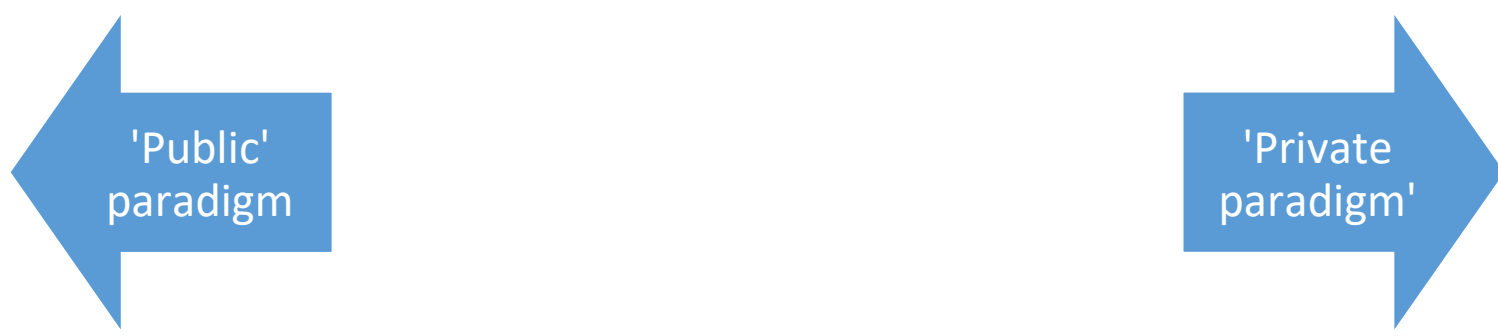

\section{Fig 2 the spectrum of redress for consumers/customers}

The above figure shows the spectrum of available redress avenues for financial customers/consumers. At one end is publicly enforced redress, which allows customers/consumers to obtain compensation as part of public enforcement against a wrong-doing firm. The FCA can make a 'restitution order' so that firms make compensation to their customers for contraventions of regulatory rules which have resulted in profits made for the firm. ${ }^{195}$ This power is somewhat sparingly used ${ }^{196}$ as the FCA's enforcement guidance on the circumstances under which it would

\footnotetext{
${ }^{194}$ FCA, SME Access to the Financial Ombudsman Service (2018) at https://www.fca.org.uk/publications/policystatements/ps18-21-sme-access-financial-ombudsman-service-near-final-rules.

195 S382, FSMA 2000 and s383, 384 deals in particular with profits made from market abuse.

196 There has been one restitution order sought against Capital Alternatives to repay 13 investors in its unauthorised collective investment schemes, see FCA v Capital Alternatives Ltd \& Ors [2014] EWHC 144 (Ch); and one in respect of market abuse.
} 
seek a restitution order places much emphasis on the limited resources on its part and that claimants could seek their personal remedies. ${ }^{197}$

Moving along the spectrum, the provision of the Financial Ombudsman Service, ${ }^{198}$ which began as an informal dispute resolution forum for individual consumers claiming up to $£ 150,000$, has been regarded as offering a necessary and accessible form of out-of-court resolution for claimants daunted by the costly civil litigation process. ${ }^{199}$ The FCA has after consultation decided to widen access to small businesses, ${ }^{200}$ for claims up to $£ 350,000$ against regulated persons. As the Ombudsman is able to determine matters based on common understandings of fairness without being constrained by legal principles, ${ }^{201}$ this avenue of redress as a public service is highly valued but aggrieved financial customers/consumers must initiate the process, and recognise that they forego rights to sue in court as the Ombudsman's decision is final. ${ }^{202}$ Commentators ${ }^{203}$ have also found in a comparative study between collective litigation and collective out-of-court dispute resolution (including financial ombudsman's services) that the latter allows access to justice with lower transaction costs and produces consistency in outcomes. Hence, promoting access to the Ombudsman is a right step forward.

Public paradigms in enforcement are important for customer/consumer redress as access to justice is perceived to be at a lower personal cost. Further, consumers in particular may be ill-empowered to consider their redress options for lack of knowledge, ${ }^{204}$ or may be subject to inertia and other behavioural limitations from pursuing genuine grievances. Public paradigms in enforcement can perform a "nudge' ${ }^{205}$ function towards improving financial consumers" positions by reducing barriers to access. Taking cues from the US Consumer Financial Protection Bureau's habitual coupling of regulatory enforcement with the making of compensation orders, there could be a 'libertarian paternalistic ${ }^{206}$ case for boosting public paradigms in enforcement such as making restitution orders a more regular feature accompanying enforcement. The cost to the FCA may be outweighed by the boost in consumer trust and confidence in financial markets and an increased deterrent effect against regulatory contraventions. However, the FCA was criticised to be ineffective in 'mission drift' towards adjudicatory roles before the Treasury Select Committee in 2016, and may therefore be less incentivised to take leadership in coupling public enforcement and consumer redress. We think the regulator's leadership should not be scaled back but instead augmented. In light of the unlikely prospect that public enforcement would be more tightly coupled with customer redress, the options

\footnotetext{
197 Chapters 11.1, 11.2, Enforcement Guide (Restitution and Redress).

198 Part XVI, FSMA 2000.

199 Lloyd Review of the Financial Ombudsman Service 2018 at https://www.financialombudsman.org.uk/publications/pdf/independent-review-2018.PDF pointing out the undisputed usefulness of the Service although improvement is needed in relation to staff training and competence, communications, governance, culture and quality assurance.

${ }^{200}$ Defined as SMEs with fewer than 50 employees, annual turnover of under $£ 6.5 \mathrm{~m}$ and an annual balance sheet total of under $£ 5 \mathrm{~m}$.

${ }^{201} R$. (on the application of IFG Financial Services Ltd) v Financial Ombudsman Service Ltd [2005] EWHC 1153.

${ }^{202}$ Clark v In Focus Asset Management \& Tax Solutions Ltd, [2014] EWCA Civ 118.

${ }^{203}$ Vicki Waye and Vince Morabito, 'Collective Forms of Consumer Redress: Financial Ombudsman Service Case Study' (2012) 12 Journal of Corporate Law Studies 1.

${ }^{204}$ See n135.

205 Cass R Sunstein and Richard Thaler, Nudge (Penguin, 2009).

206 Cass R Sunstein and Richard H Thaler, 'Libertarian Paternalism is not an Oxymoron' (2003) 70 University of Chicago Law Review 1159.
} 
along the spectrum towards 'private paradigms' in Figure 2 above would crucially need to be improved.

The FCA has powers to order consumer redress schemes ${ }^{207}$ where a widespread or regular failure by firms to comply with regulations is perceived, resulting in customer losses. These schemes are out of court compensation schemes administered by firms and could be regarded as a convenient and efficient means of securing large-scale consumer redress without lengthy and costly processes in litigation. The FCA has made more use of this redress avenue for consumers rather than restitution orders. However, the schemes are principally delegated to firms to investigate each claim and make valuations of award, and there are reports of mixed experiences by claimants. ${ }^{208}$ The 'public' nature of the consumer redress scheme only lies in its inception and claims processes and outcomes are 'privatised' for firms to manage. This is arguably confirmed in the Holmcroft Properties decision ${ }^{209}$ where a claimant who was unhappy with the award given by Barclays under a consumer redress scheme was held unable to challenge the decision of the independent valuer hired by Barclays via judicial review proceedings. This is because the valuer's job was of a private and not public nature. The only recourse for the claimant would be to proceed to civil litigation against Barclays which is likely unaffordable. ${ }^{210}$

Consumer redress schemes may be regarded as quasi-public in nature as they seem to strike a balance between a fully public-backed restitution order and leaving claimants to private litigation. However, key issues of dispute resolution are left to private negotiations such as liability and value of award and the FCA does not maintain oversight of the administration of the schemes. Sub-optimal administration by firms can result in practical barriers to justice, and it is argued that the dominant bilateral or transactional narrative underlying the Holmcroft characterisation of the consumer redress scheme is out of step with the modern context of widespread financialisation and a poor track record on the part of large and trusted institutions to serve consumers fairly and ethically.

At the other end of our spectrum towards 'private paradigms', customers/consumers can rely on private complaints made to firms, or private litigation where negotiations have broken down. Although having robust complaint processes is a mandatory organisational requirement for financial services providers, ${ }^{211}$ organisational regulation in finance can be highly meta-regulatory in nature. This means that firms are left to implement certain broadly framed requirements. ${ }^{212}$ In financial regulation, some organisational regulations have become more intrusive, prescribed and subject to supervision because of lessons learnt with the benefit of hindsight ${ }^{213}$ but not all organisational regulations are equally intense. The institution of complaints processes at firms is subject to the requirements of being effective, transparent, reasonable and prompt, ${ }^{214}$ with a few specific prescriptions such as providing a free number to call for complaints and to resolve a complaint by

\footnotetext{
207 S404, FSMA 2000.

${ }^{208}$ FCA, Thematic Review: Complaints Handling (Nov 2014) at https://www.fca.org.uk/publication/thematicreviews/tr14-18.pdf.

${ }^{209}$ Re Holmcroft Properties Ltd, KPMG LLP, FCA and Barclays Bank plc [2016] EWHC 323.

210 See discussion in Section A.

${ }^{211}$ FCA Handbook DISP, and Art 26, MiFID Commission Delegated Regulation 2017/565/EU, which requires effective and transparent complaints handling processes to be established at firms and to be monitored by the compliance function.

212 See $n 153$.

213 In particular in relation to anti-money laundering, see FCA Handbook SYSC 6.3 and the Joint Money Laundering Steering Committee Guidelines 2018 at http://www.jmlsg.org.uk/ which is very detailed. ${ }^{214}$ FCA Handbook DISP 1.1A, 1.3 for MiFID and non-MiFID business.
} 
the end of the third business day. ${ }^{215}$ The FCA has carried out a thematic review of complaintshandling processes and found a mixed picture of optimal practices in 2014. The privatised or bilateral context between firm and customer continues to require monitoring, and the FCA has since 2016 published firms' complaints data so as to 'nudge' them into better practices by peer level transparency and comparison. ${ }^{216}$

Private litigation remains important for customer/consumer redress where specific justice can be sought and where claimants are sufficiently resourced. Although we would like to see more FCA oversight of consumer redress schemes and stronger regulatory leadership in improving firms' complaint-handling culture, private litigants should have credible recourse to the courts in an accessible manner. The opportunity for courts to develop jurisprudence is highly valuable although a similar opportunity arguably exists where courts decide on a restitution order for which the FCA must seek in court. ${ }^{217}$ The barriers to access are generally high, ${ }^{218}$ but in this regard, a number of proposals have been made by Samuel to improve access to private justice by instituting a Financial Services Tribunal which could be a new creation or a recalibration of the existing Upper Tribunal for Tax and Chancery which currently hears references by persons aggrieved by FCA enforcement decisions against them. ${ }^{219}$ Samuel $^{220}$ is of the view that a specialist tribunal provides development of law in an openly contested manner, and is much more robust than the regulator's enforcement of law or the Ombudsman's dispute resolution. The quality of justice that can be achieved is regarded to be superior to regulator-supported schemes such as the consumer redress scheme discussed above. Such a tribunal would not have compensation limits like the Ombudsman and can provide lower cost of access to justice.

We see these proposals as being consistent with the case we have made so far in relation to the social footprint of financialisation and the need for there to be effective mechanisms where redress is called for. Where collectively and public led action may not meet the needs of individual cases, accessibility to private litigation is important. In this respect, we argue that there is no need to maintain a 'private person' limitation under 5138D of the Financial Services and Markets Act for breaches of statutory duty. The series of small business litigation discussed earlier could have provided opportunities for the court to refine jurisprudence on client classification or the expectations of the duty of appropriateness but this was not possible due to the bar against the litigants, forcing them to seek other causes of action in general law that ultimately did not meet their needs. The courts should be given the opportunity to clarify and develop the law on regulatory duties. We note that Ireland has enacted a right to private action for breaches of statutory duty in

\footnotetext{
${ }^{215}$ FCA Handbook DISP 1.3.

${ }^{216}$ From 2016, the FCA began to collect complaints data from firms, see https://www.fca.org.uk/data/complaints-data.

217 S382-4, FSMA 2000.

${ }^{218}$ Richard Samuel, 'Tools for Changing Banking Culture: FCA Are You Listening?: Why the FCA's IRHP Mass Dispute Resolution System Has Failed and What the FCA Can Do about It' (2016) 11 Capital Markets Law Journal 129; 'The FCA Has Now Listened: Banks, It Is in Your Interests to Listen Too' (2018) 13 Capital Markets Law Journal 3.

219 Part IX, Financial Services and Markets Act 2000 and amended; discussed in Richard Samuel, 'Tools for Culture Change: FCA, Now You Are Listening! Time to Build an Independent, Low Cost Forum for Conduct Dispute Resolution' (2016) 12 CMLJ 277.

${ }^{220}$ First proposed in Richard Samuel, 'Tools for Changing Banking Culture: FCA Are You Listening?' (2015) 11 CMLJ 129, developed in Samuel (2016) above and in 'The FCA Has Now Listened: Banks, It Is In Your Interests to Listen Too' (2017) 13 CMLJ 3.
} 
financial regulation to all litigants, ${ }^{221}$ which is a model that can be considered. We are sceptical that financial firms would be overwhelmed by frivolous floodgates of litigation as causation of loss still needs to be proved in each civil claim and enacting the right is not equivalent to opening the gates to recovery. Further, wisdom from the 'law and finance' research ${ }^{222}$ may suggest that strengthening the avenues of civil litigation as a form of discipline can, in a time of low public esteem for financial firms, ${ }^{223}$ improve perceptions of market fairness and customer confidence.

\section{Conclusion}

A perceived need to improve consumer/customer protection in financial services underlies the FCA's consultation on a possible new duty of care. We argue that embarking on such reform as if it provides a silver bullet is a misplaced course of action, given that the 'duty of care' suffers from legal baggage not particular helpful to claimants' cases in jurisprudential development to date. We articulate a more comprehensive agenda for considering customer/consumer protection reforms, and frame four areas of policy choices for the FCA, in relation to scope of protection, standards of protection, enforcement policy and redress avenues. Each of these areas present specific policy choices relating to gaps or shortfalls of the existing regulatory regime, some of which are also being discussed in other FCA papers. There is a need for more joined-up, coherent and comprehensive thinking, and the boldness to articulate clear policy choices, in order to achieve the regulatory mandate of effective consumer protection.

\footnotetext{
${ }^{221}$ Elizabeth Corcoran and John Breslin, 'New Private Right of Action for Damages in Financial Services Litigation' (2015) Dublin University Law Journal 17.

222 R La Porta el al, 'What Works in Securities Laws' (2006) 61 Journal of Finance 1.

${ }^{223}$ Roman Tomasic and Folarin Akinbami, 'The Role of Trust in Maintaining the Resilience of Financial Markets' (2011) 11 Journal of Corporate Law Studies 369, PwC, How Financial Services Lost Its Mojo - And How It Can Get It Back (2014) at https://www.pwc.co.uk/assets/pdf/fsrr-consumer-survey-final.pdf.
} 